\title{
Interpretação do P-CMM como facilitador da melhoria de processo de software
}

\author{
Rodrigo Fantinatti Teixeira
}

Orientadora: Profa. Dra. Rosely Sanches

Dissertação apresentada ao Instituto de Ciências Matemáticas $\epsilon$ de Computação - ICMC-USP, como parte dos requisitos para obtenção do título de Mestre em Ciências - Área: Ciências de Computação e Matemática Computacional.

USP - São Carlos

Junho de 2000 


\section{Agradecimentos:}

À minha orientadora, Prof ${ }^{\mathrm{n}}$. Dra. Rosely Sanches, não apenas por acreditar neste trabalho e orienta-lo com inacreditável maestria, mas principalmente pela confiança e motivação dispensada durante este projeto.

Ao Prof. Dr. Edmundo Escrivão Filho, pela disposição em contribuir de maneira decisiva com este trabalho em diversas ocasiões.

Aos meus pais e a minha irmã que sempre apoiaram e se orgulharam desse projeto.

E principalmente à minha amiga e namorada, Maria Paula, pela compreensão nos momentos de ausência e pela motivação contínua durante todo este trabalho. 
LISTA DE TABELAS .................................................................................... III

LISTA DE FIGURAS.......................................................................................

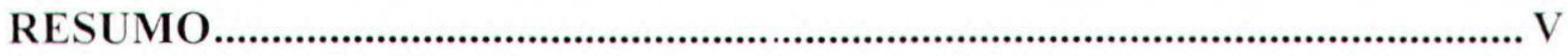

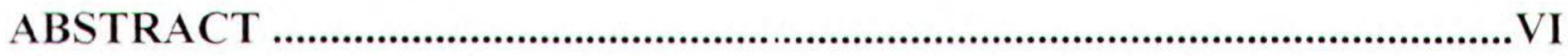

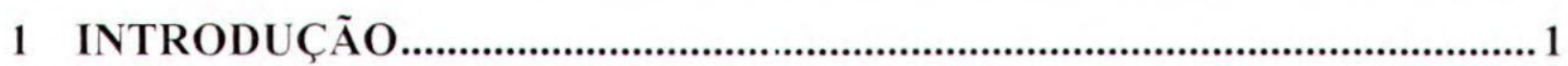

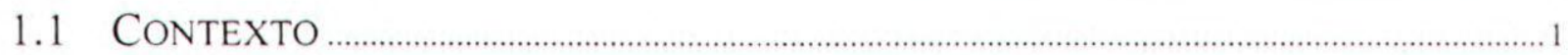

1.2 MOTIVAÇÃO

1.3 OBJETIVOS

1.4 ORGANIZAÇÃO DO TRABALHO

2 O PEOPLE CAPABILITY MATURITY MODEL …................................ 7

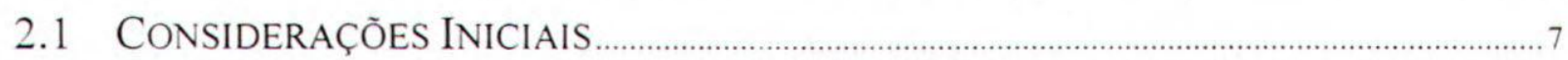

2.2 Contextualizando o People Capability Maturity Model ………...............

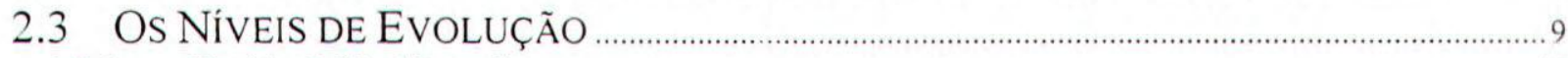

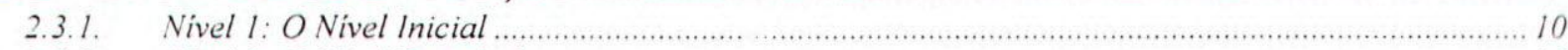

2.3.2. Nivel 2: O Nivel Repetivel .................................................................................

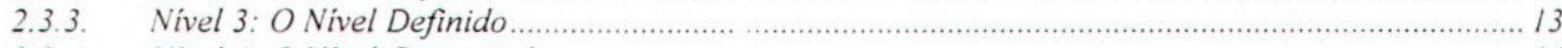

2.3.4. Nivel 4: O Nivel Gerenciado .........................................................................................16

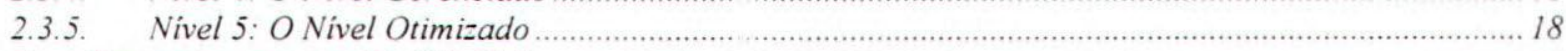

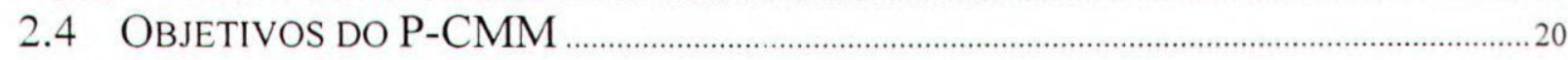

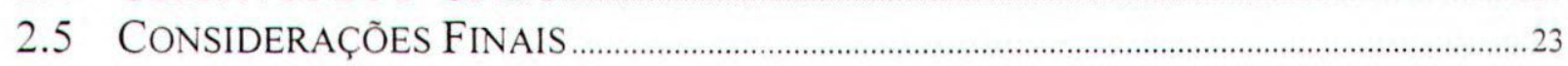

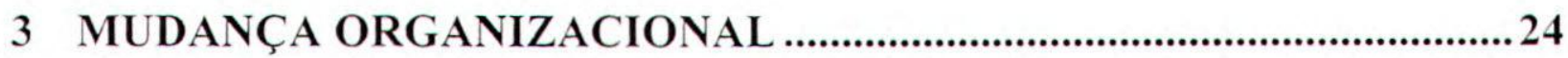

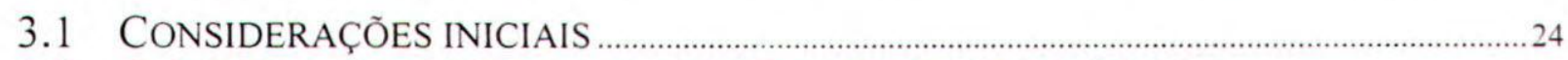

3.2 O Sistema ORganizacional E O PROCESSO DE MudANÇA .................................24

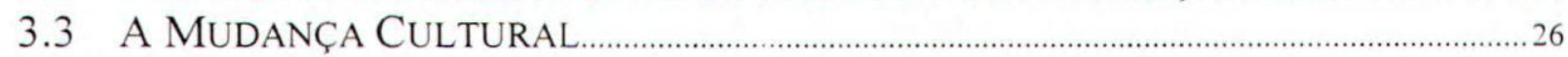

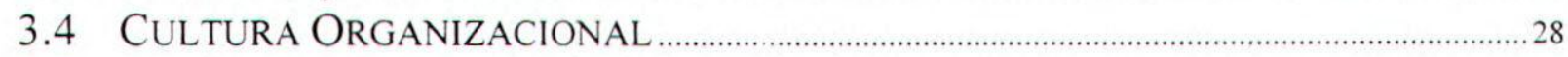

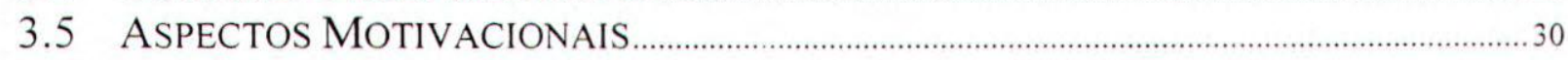

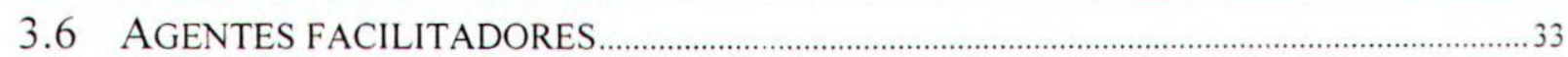

3.7 A InfluÊNCIA do ENFoque Estrutural na MudanÇA Cultural..................36

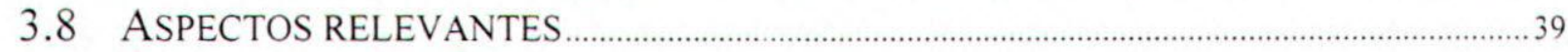

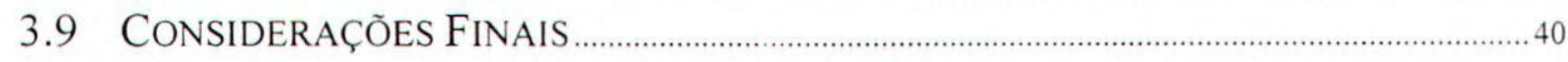

4 O P-CMM COMO AGILIZADOR DE MUDANÇAS.................................. 41

4.1 CONSIDERAÇÕES INICIAIS ..................................................................................... 
4.2 ÁREAS DE ATUAÇÃO PARA QUEBRA DE BARREIRAS ……............................................ 41

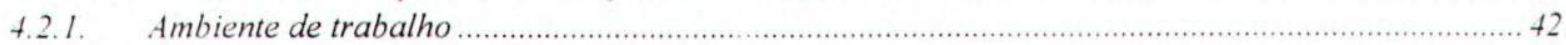

4.2.2. Comunicação

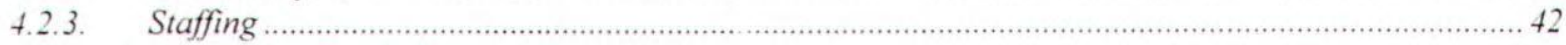

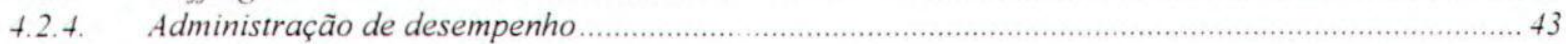

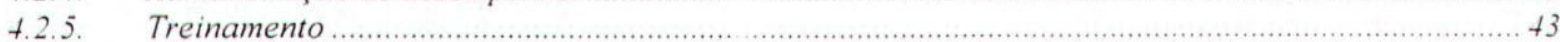

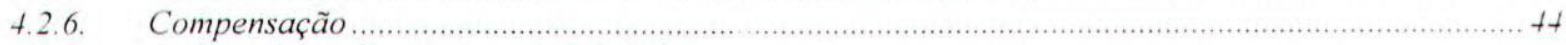

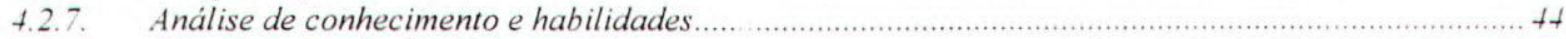

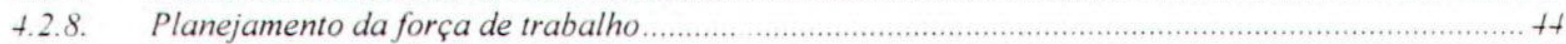

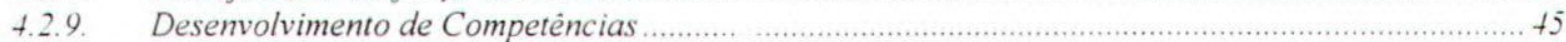

4.2.10. Desenvolvimento de Carreira

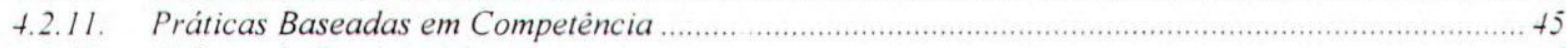

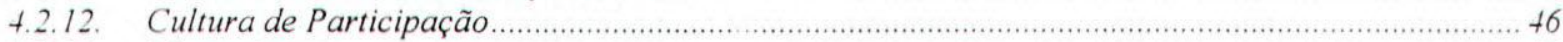

4.2.13. Mentoring

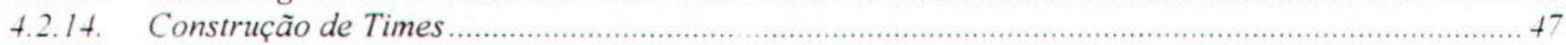

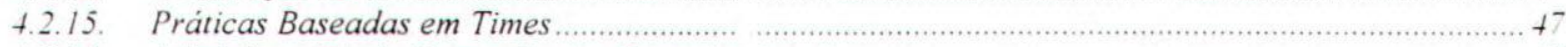

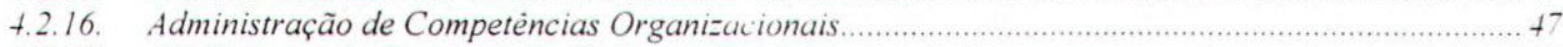

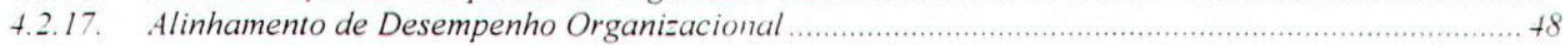

4.2.18. Desenvolvimento de Competência Pessoal …...................................................................48

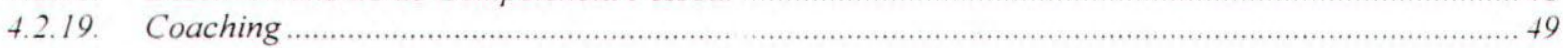

4.2.20. Inovação Continua da Força de Trabalho

4.3 OBJETIVOS GERAIS NO PROCESSO DE MUDANÇA .........................................................49

4.4 KPAS PRIORITẢRIAS PARA FACILITAR A MELHORIA DE PROCESSO …......................51

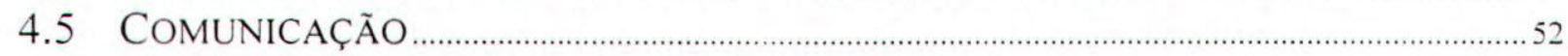

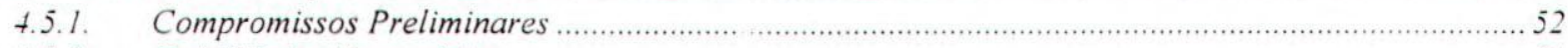

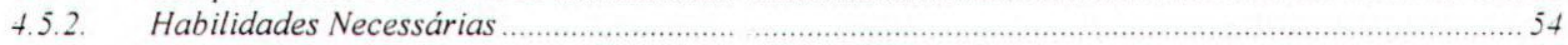

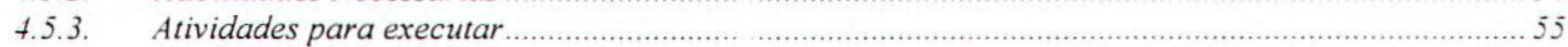

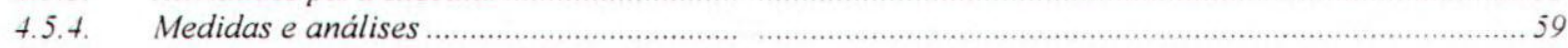

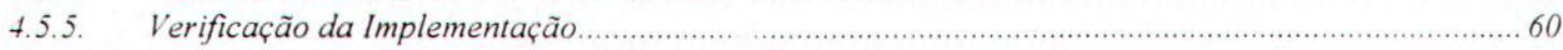

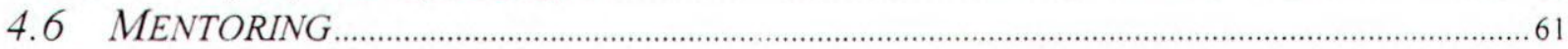

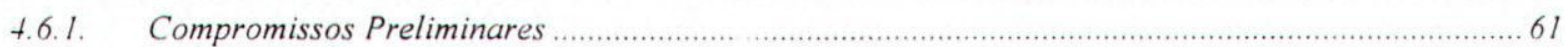

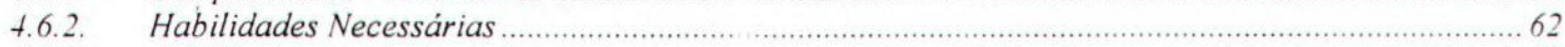

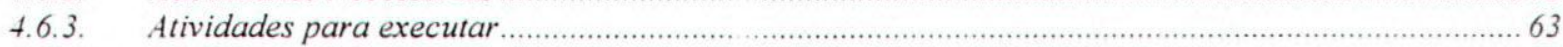

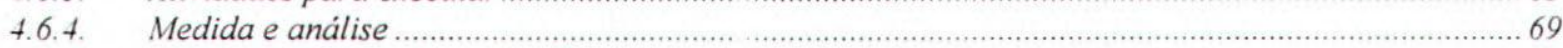

4.6.5. Verificação da Implementação

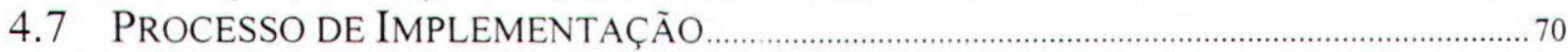

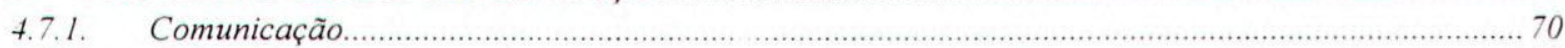

4.7.2. Mentoring

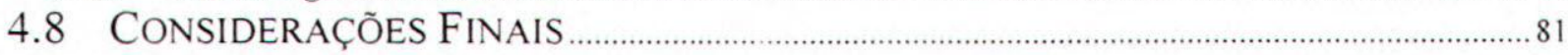

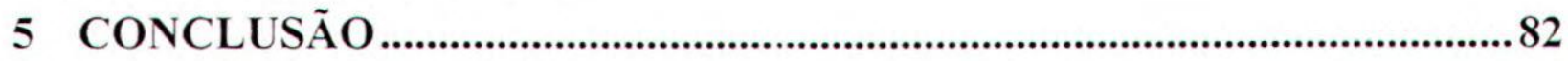

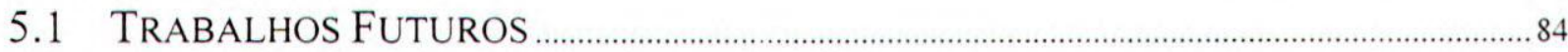

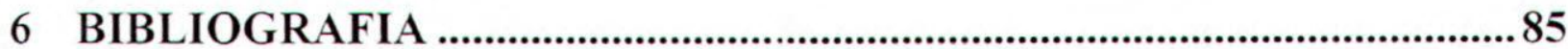

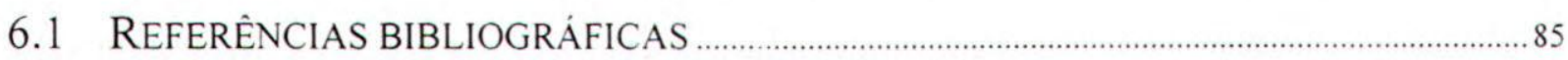

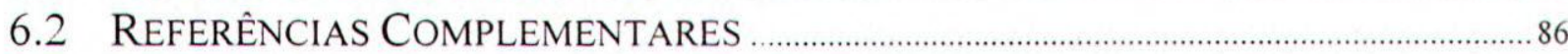


LISTA DE TABELAS

Tabela 2-1: Histórico do P-CMM

8

Tabela 2-2: Temas do P-CMM

Tabela 3-1: Ciclo VIDA de motivação

22

Tabela 4-1: Resumo KPAs X Aspectos organizacionais

32 
LISTA DE FIGURAS

Figura 2-1: Os níveis do P-CMM 10

Figura 4- I: Resumo da KPA Comunicação 71

Figura 4-2: Processo de implantação da Comunicação 74

Figura 4-3: Resumo da KPA Mentoring 76

Figura 4-4: Processo de implantação do Mentoring 


\section{Resumo}

Dificuldades e empecilhos encontrados na melhoria de processn te enftrx/are são em grande parte fruto das barreiras colocadas pelas pessoas envoıvıuas «u processo. Neste trabalho o P-CMM (People Capability Maturity Model) é interpretado com a intenção de minimizar essas barreiras. Também são apresentados como duas áreas chave de processo do P-CMM, consideradas como as mais importantes para facilitar a melhoria de processo de software, Comunicação e Mentoring, podem ser implantadas em empresas de pequeno e médio porte. 
Abstract

Difficulties and problems found largely in the improvement of process of software come from the barriers placed by the people involved in the process. In this work P-CMM (People Capability Maturity Model) it is interpreted with the intention of minimizing those barriers. They are also presented as two key process areas of P-CMM, considered as the most important to facilitate the improvement of software process, Communication and Mentoring, they can be implanted in companies of small and medium load. 


\section{INTRODUÇÃO}

\subsection{Contexto}

De acordo com a pesquisa de 1997 do Ministério da Ciência e Tecnologia (Qualidade, 1998), $41,7 \%$ das empresas de informática são compostas por 1 a 10 pessoas e $43,1 \%$ por 11 a 100 pessoas, o que indica que as empresas de software brasileiras são, em sua maioria, de pequeno e médio porte. Mesmo nessas empresas, a qualidade já é uma preocupação constante, pois segundo a mesma pesquisa, $36 \%$ das empresas de software estão estudando a implantação de um programa de qualidade e $18 \%$ já estão implantando algum programa. A demanda por qualidade nos produtos de software vem crescendo a cada dia.

Apesar da importância, o estudo da qualidade de software é recente e o que hoje se trata como qualidade está muito associado a atividades de teste. No entanto, qualidade é um tópico muito mais complexo do que isso. Ao implantar-se um programa de melhoria de qualidade de software procura-se minimizar os riscos para quem utiliza o software através da garantia de um conjunto de atributos. Esses atributos devem ser satisfeitos de modo que o software atenda às necessidades dos usuários. A qualidade do software deve ser medida, definida, monitorada, gerenciada e melhorada.

A qualidade de software é fruto da trilogia, tecnologia, processo e pessoas, que participam do processo de desenvolvimento de software. Os primeiros modelos de qualidade apontavam para as atividades e técnicas que garantiam a qualidade e melhoria do produto de software, ou seja, do software já finalizado. Dessa forma focalizava-se apenas a tecnologia usada e menosprezava-se o processo e as pessoas envolvidas.

Atualmente muitos modelos de qualidade já focam a melhoria do processo e as idéias de melhoria contínua, mas ainda dão pouca atenção para o fator humano envolvido. E não se pode pensar em melhorar a qualidade do software através de apenas um ou dois dos vértices do triangulo, tecnologia, processo e pessoas. 
Os coordenadores, lideres e responsáveis por melhorar a qualidade de software precisam ver o desenvolvimento de software como um conjunto de recursos interligados e que qualquer alteração em um dos elementos da trilogia, só ocorrera através de mudanças em outras partes da organização.

\subsection{Motivação}

Os modelos de melhoria de processo atuais, já são complexos e bem estruturados. Modelos como SW-CMM (Capability Maturity Model for Software), possuem um sólido framework que se utiliza das boas práticas da engenharia de software para através da melhoria contínua, melhorar a qualidade do processo de software e conseqüentemente a qualidade do software. Mas esses modelos esquecem dos outros recursos que compõem o desenvolvimento de software e que devem ser administrados e melhorados, que são os recursos tecnológicos e os recursos humanos.

É importante perceber que a empresa que desenvolve software, assim como qualquer outra empresa, antes que "seja pensada como um conjunto de máquinas e equipamentos, ou como uma estrutura formal que distribui funções ou procedimentos, sistemas e computadores, talvez deva ser pensada como organização social e humana. Esse lembrete, embora óbvio, tornase cada dia mais importante, pois se constata que muitos administradores e especialistas estão progressivamente mergulhados em soluções técnicas, em soluções racionais, ao mesmo tempo em que o clima, do ponto de vista humano, parece estar, em boa parte das empresas, cada dia mais tenso, desgastante, pouco motivador etc." (Rodrigues, 1995, pag 172).

Esses problemas encontrados em muitas organizações são mais visíveis e graves em organizações mais dependentes da capacidade dos recursos humanos, como por exemplo, a industria de serviços e a industria de informática. Essas organizações são basicamente empresas de produção intelectual, sofrendo pouca influência dos equipamentos de apoio envolvidos.

$\mathrm{Na}$ industria de software, por exemplo, o desenvolvimentó de software é uma atividade ampla, integrada, e basicamente um trabalho puramente intelectual, dessa forma a habilidade no desenvolvimento de software é a habilidade em administrar toda a complexidade intelectual que 
se encontra em um projeto de software. Além disso, fala-se de um ambiente onde a obsolescência do conhecimento acontece com espantosa rapidez. o que torna a mudança mais crucial, mas também mais delicada.

Dessa maneira explica-se muitos insucessos de projetos de melhoria de processo de software, pois a mudança no processo de desenvolvimento passa necessariamente pelos seus recursos humanos e :mudar as pessoas de uma organização, assim como todo processo de mudança. leva consigo uma enormidade de dificuldades e empecilhos inesperados. Isso porque os recursos humanos estão interligados ao sistema afetando e sendo afetados por outras partes. Sendo assim, "esforços de melhoria de processo rompem ecossistemas delicados e profundamente arraigado dentro da comunidade. Processos de mudança envolve mudança cultural, repleta com todas as dificuldades inerentes à mudança das percepções, valores, e comportamentos normativos de uma comunidade" (Appleton. 1997).

A resistência das pessoas é uma das maiores fontes de insucesso dos processos de mudança e se forma por vários aspectos, que muitas vezes estão relacionados diretamente a cultura da empresa. A cultura indica para as pessoas a maneira como resolver seus problemas, a dificuldade é que "esta 'forma' de lidar com us problemas se torna uma 'fôrma', isto é, um molde que passa a sinalizar para os membros da organização que aquela é a única maneira. ou a maneira correta de sentir, pensar e agir com relação às diversas situações. Assim, a tendência natural da maioria das organizações, seria muito mais no sentido de preservação de padrões culturais do que de mudança" (Fleury, 1991).

Além da cultura, o ambiente influência no processo de mudança. "Nos períodos de estabilidade, as resistências a modificações em qualquer instância da vida organizacional são muito fortes, justificadas pelo clássico não se mexe em time que esta ganhando", (Fleury, 1989).

No entanto, para que a mudança seja eficiente e positiva, não basta identificar e destruir as barreiras a ela, é necessário compreender essas barreiras e efetivamente administra-las. É importante lembrar que "a resistência é normal e saudável e algumas vezes ela contém prudência que merece atenção. Outras vezes, porém, é uma inércia que prevalece apesar do mérito da mudança..." (Siddall, 1997). As barreiras às mudanças estão espalhadas por todo o sistema organizacional, desde a cultura existente na empresa até a maneira como cada gerente, cada líder se relaciona com seus colaboradores.

Entender e gerenciar esses conceitos não são fáceis e muitas vezes não são sequer entendidos, pois os gerentes de projeto de sofiware são, na maioria das vezes, engenheiros de 
software vindos diretos de funções técnicas para funções administrativas sem qualquer preparo prévio. Pode-se assim imaginar que qualquer esforço de agilizar mudanças e capacitar os gerentes de projetos de software a lidar com seu pessoal durante essa mudança, é de grande interesse para a industrias de software.

\subsection{Objetivos}

Resistência das pessoas, falta de comprometimento e desinformação são apenas alguns dos problemas normalmente encontrados durante a implantação da melhoria de processo de software. Por traz desses problemas, está a falta de visão que os responsáveis pela melhoria do processo de software tem da interligação dos recursos que formam os sistemas organizacionais o que afeta drasticamente o sucesso desses programas.

Considerando-se os três componentes básicos de uma organização, (Bio, 1985), que são: o hardware (representa os equipamentos, a infra-estrutura e o maquinário necessário para a fabricação de produtos ou prestação de serviços), o software (representa as rotinas e o conhecimento já sistematizado, utilizado na fabricação de produtos ou prestação de serviços) e o humanware (representa as pessoas que contribuem para o processo produtivo com trabalho ou conhecimento ainda não-sistematizado), tem-se que qualquer mudança em um desses recursos certamente afeta os outros.

$\mathrm{Na}$ tentativa de compreender melhor conı o humanware interage com os outros recursos, neste trabalho, estuda-se as dificuldades de implantação da melhoria de processo sob o foco das pessoas, ou seja, procura-se entender como os gerentes de projetos e administradores podem enfrentar as barreiras impostas por seus recursos humanos, durante a melhoria de processo, e como podem administrar as pessoas para que essa melhoria seja ágil e traga mais qualidade ao software desenvolvido, como os tempos atuais exigem.

A escolha das pessoas como centro do sistema é uma tendência evoluída ao longo de toda a história industrial onde os recursos têm sido tratados de maneira diferenciada, de acordo com a relevância dada a cada um. No início da sociedade industrial, o componente predominante, em termos de valor, era o hardware. O software tornou-se então mais importante, adquirindo valores 
equivalentes aos do hardware. Assim, o software e hardware tornaram-se os principais componentes do processo. Hoje, as pessons tornaram-se o principal componente das organizações (Bio, 1985).

Neste trabalho, identifica-se as barreiras e dificuldades impostas pelas pessoas em um processo de mudança e procura-se ambienta-las para a realidade da melhoria de processo de software. Com isso pretende-se identificar maneiras de gerenciar essas barreiras minimizando o seu efeito no sucesso da melhoria de processo.

Para ajudar nessa ambientalização utilizou-se o P-CMM (People Capability Maturity Model). um modelo de maturidade para o desenvolvimento do talento humano, desenvolvido pela SEI (Software Engineering Institute, pertencente à universidade Carnegie Mellon). O PCMM tem como objetivo estratégico a melhoria das capacidades das organizações de software, através do aumento da capacidade da sua força de trabalho, assegurando que a capacidade de desenvolvimento de software seja um atributo da organização e não apenas de alguns poucos indivíduos. isso alinha a motivação dos indivíduos com a da organização, retendo então os recursos humanos dentro da organização.

Esse modelo foi escolhido por ser o primeiro modelo de melhoria da qualidade de software a atuar no vértice humano dos recursos que desenvolvem o software. É importante perceber, no entanto, que não é objetivo deste trabalho indicar como aplicar o P-CMM durante a melhoria de processo. Sendo assim, não será analisado o framework do P-CMM dentro de um programa de melhoria de processo de software.

O que se pretende neste trabalho é identificar quais áreas chaves de processo podem ser utilizadas para ininimizar as barreiras impostas pelas pessoas, durante a melhoria de processo de software. Dessa forma, faz-se uso da estrutura, nomenclatura e análise já consagrada e ambientada às características da engenharia de software, para introduzir esses novos conceitos estudados. 


\subsection{Organização do trabalho}

Esse trabalho está organizado em cinco capítulos. Além desta introdução, o trabalho traz no capitulo seguinte uma revisão bibliográfica do modelo P-CMM, com sua estrutura e objetivos. Ainda como revisão bibliográfica, no capitulo três é mostrado a visão da área de administração de empresas sobre o processo de mudança, através da mudança cultural e do gerenciamento de pessoas.

Como resultado do trabalho no capitulo quatro é descrito uma nova interpretação do PCMM, utilizando-se as teorias administrativas. Ainda como resultado nesse mesmo capítulo mostra-se a escotha de algumas KPAs do P-CMM que podem ajudar a minimizar barreiras durante a melhoria de processo. Mostra-se também como essas KPAs podem ser implantadas em uma empresa.

No capitulo cinco conclui-se o trabalho com as observações finais, conclusões extraidas e expectativas de trabalhos futuros. 


\subsection{Considerações Iniciais}

Neste capítulo é apresentado o P-CMM (People Capability Maturity Model), um modelo de maturidade para o desenvolvimento do talento humano. No capitulo também é descrito os objetivos gerais do modelo, dentro do contexto em que ele foi desenvolvido. Na sequêencia apresenta-se a solução para alcançar esses objetivos, identificada através do estudo de cada nivel no processo de evolução e suas correspondentes áreas chave de processo.

\subsection{Contextualizando o People Capability Maturity Model}

O P-CMM (Curtis et all, 1995) é um modelo que descreve um caminho de melhoria evolutiva de um nível ad hoc, onde as práticas são inconsistentemente executadas, para um nivel maduro, onde o desenvolvimento do conhecimento, das habilidades, e da motivação da força de trabalho é disciplinado. O P-CMM auxilia as oryanizações de software a:

$\Rightarrow$ Caracterizar a maturidade das práticas de sua força de trabalho;

$\Rightarrow$ Guiar um programa contínuo de desenvolvimento de força de trabalho;

$\Rightarrow$ Fixar prioridades para ações imediatas;

$\Rightarrow$ Integrar desenvolvimento de força de trabalho com melhoria de processo;

$\Rightarrow$ Estabelecer uma cultura de excelência em engenharia de software.

Esșes conceitos foram inicialmente concebidos por Bill Curtis no primeiro workshop sobre CMM (Capability Maturity Model) da SEI (Software Engineering Institute, pertencente à 
universidade Carnegie Mellon) em 1988. Um projeto para desenvolver o modelo foi anunciado no Simpósio da SEI em 1992; com o objetivo de estender o gerenciamento e a perspectiva organizacional do Capability Maturity Model para Software para incluir o gerenciamento dos recursos humanos necessários para o desenvolvimento e manutenção de sistemas de software.

Dando sequêencia a iniciação do projeto, uma assembléia consultiva do P-CMM foi formada em julho de 1993. Essa assembléia foi formada por indivíduos experientes em engenharia de software, desenvolvimento e gerenciamento de sistemas de informação e recursos humanos. A versão 0.1 do P-CMM foi liberada para revisão pela assembléia consultiva em outubro de 1993. A atual versão 1.0 foi lançada no Simpósio de Engenharia de Software da SEI entre 11 e 14 de setembro de 1995 em Pittsburglı. Pensilvânia. A tabela 2-1 mostra o histórico do modelo.

\begin{tabular}{|l|c|l||}
\hline \multicolumn{2}{|c|}{ Datá } \\
\hline Agosto de 1990 & 0.0 & Publicação do modelo conceitual [Curtis90] \\
\hline Outubro de 1993 & 0.1 & Versão para revisão pela assembléia consultiva \\
\hline $\begin{array}{l}\text { Novembro de } \\
1994\end{array}$ & 0.2 & $\begin{array}{l}\text { Rascunho para revisĩo pública. Versão 0.2 distribuida para o grupo de } \\
\text { correspondência do P-CMM para revisão e comentários. }\end{array}$ \\
\hline Abril de 1995 & 0.3 & $\begin{array}{l}\text { Rascunho para revisão pública. Versão 0.3 distribuída para o grupo de } \\
\text { correspondência do P-CMM para revisão e comentários. }\end{array}$ \\
\hline Setembro de 1995 & 1.0 & Versão base liberada áo público \\
\hline
\end{tabular}

Tabela 2-1: Histórico do P-CMM

As práticas caracterizadas pelo P-CMM foram escolhidas da experiência industrial considerando as que têm impacto significante no indivíduo, time, unidade, e no desempenho organizacional. Quando uma organização alcança um novo nível de maturidade no P-CMM, novas capacidades são institucionalizadas. conseqüência do programa de melhoria organizacional, resultando em um aumento global na capacidade da força de trabalho da organização. Crescendo pelos niveis de maturidade cria-se mudanças fundamentais na administração das pessoas e na cultura na qual elas trabalham.

Como um modelo de maturidade da competência, o P-CMM orienta a organização no estabelecimento e na melhoria das suas práticas da força de trabalho através de cinco estágios evolucionários. A conclusão de cada nível de maturidade no P.CMM institucionaliza novas competências para o desenvolvimento do conhecimento e das habilidades da força de trabalho, 
resultando num crescimento global das habilidades da organização. A melhoria crescente através dos niveis de maturidade provoca mudanças fundamentais em como as pessoas desenvolven e se organizam e na cultura de trabalho.

O P-CMM é um dos modelos de uma familia de modelos criados pela SEI que utiliza o framework CMM. Dentre os modelos dessa familia que estão atualmente em desenvolvimento. expansão ou manutenção, estão:

- CMMI $^{\text {SM }}$ - CMM Integration ${ }^{\text {SM }}$

- SW-CMM - Capability Maturity Mode ${ }^{\oplus}$ for Software

- P-CMM - People Capability Maturity Model

- SA-CMM - Software Acquisition Capability Maturity Model

- SE-CMM - Systems Engineering Capability Maturity Model

- IPD-CMM - Integrated Product Development Capability Maturity Model

\subsection{Os Níveis de Evolução}

O P-CMM é composto por cinco níveis de maturidade, sendo que cada nível de maturidade é composto por Áreas Chave de Processo (KPA) que identificam as capacidades que devem ser institucionalizadas para alcançar um nível de maturidade, descrevendo as práticas que uma organização deve implementar para melhorar sua capacidade de força de trabalho.

Cada nivel do P-CMM provê uma camada na fundação para melhoria contínua das práticas de força de trabalho de uma organização, A Figura 2-1 exibe os níveis do P.CMM com as respectivas áreas chave de processo. No nível Repetível, a organização se disciplina a executar as práticas básicas, no nível Definido, estas práticas são agrupadas para aumentar o conhecimento particular, as habilidades, e os métodos de trabalho que melhor apóiem os negócios da organização. No nível Gerenciado, a organização desenvolve times baseados em competência, alto desempenho, e empiricamente avalia como efetivamente as práticas de sua força de trabalho estão alcançando os objetivos. Por fim no nível Otimizado, a organização procura continuamente modos inovadores, para melhorar a capacidade de sua força de trabalho 
para apoiar os indivíduos na perseguição da excelência profissional. Cada Área Chave de processo foi direcionada a um único nivel de maturidade, onde identificam um conjunto de atividades relacionadas que, quando executados coletivamente, alcançam um conjunto de metas consideradas importantes para aumentar a capacidade da força de trabalho.

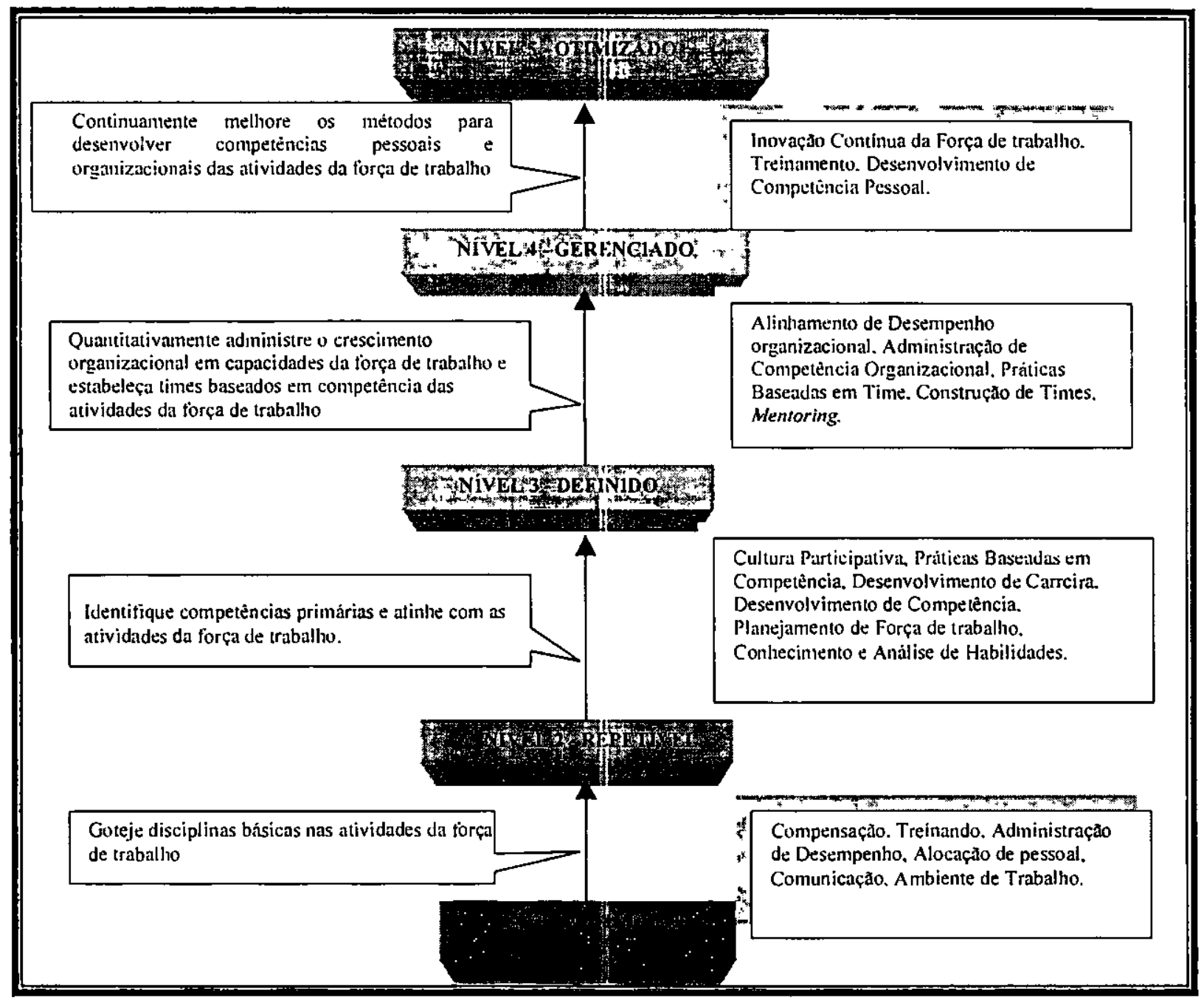

Figura 2-1: Os niveis do P-CMM

\subsubsection{Nível 1: O Nivel Inicial}

No nível Inicial, a organização provê avaliações para as atividades, mas oferece pouca liderança ou treinamento na conduta dessas atividades. Tipicamente os gerentes não são treinados para executar a maioria das responsabilidades de sua força de trabalho e assim a sua habilidade em administrar seus colaboradores está baseada nas experiências por ele vividas. 
Essas organizações não são necessariamente abusivas, o problema é que elas não têm a habilidade para desenvolver sistematicamente a capacidade competitiva da sua força de trabalho.

Nas piores circunstâncias, gerentes en organizações de Nível 1 não consideram 0 desenvolvimento da força de trabalho da sua unidade como uma responsabilidade pessoal. $O$ departamento de recursos humanos muito freqüentemente usa práticas importadas e as aplica com pequena análise da sua efetividade. Dessa forma a capacidade da força de trabalho de uma organização Nível 1 é desconhecida, pois é pequeno o esforço para medi-la ou melhora-la. Os indivíduos são motivados a procurar os próprios programas de trabalho. ao invés de alinhar as suas motivações com os objetivos empresariais da organização. O turnover é alto, pois as pessoas sentem que estariam trabalhando em melhores condições ou com maior potencial de crescimento em outra organização. Por conseguinte, o nível de conhecimento e habilidades disponíveis na organização não cresce com o passar do tempo por causa da necessidade em substituir individuos experimentados e educados que deixaram a organização.

\subsubsection{Nivel 2: O Nível Repetível}

Os objetivos primários do nível Repetivel são eliminar os problemas que impedem as pessoas de executarem as suas responsabilidades de trabalho efetivamente; e estabelecer uma fundação de práticas que possam ser melhoradas continuamente, desenvolvendo assim a força de trabalho. Os problemas mais frequentes que impedem as pessoas de serem capazes de realizar suas tarefas efetivamente, em organizações de baixa maturidade, são as distrações ambientais. os objetivos de desempenho obscuros, a falta de conhecimento pertinente ou habilidade e a comunicação pobre.

No nível Repetível, uma organização estabelece políticas direcionadas ao desenvolvimento das pessoas, sendo que um objetivo primário alcançado em uma capacidade Repetível é o estabelecimento de uma sensaçào de responsabilidade e disciplina nas práticas básicas executadas pela força de trabalho. Essas práticas asseguram que as pessoas em cada unidade terão o conhecimento e habilidades requeridas para executar a sua tarefa atual. Quando essas práticas são institucionalizadas, a organização estabelece uma fundação na qual pode construir métodos e práticas melhores.

Nesse nível, os responsáveis pela realização das atividades da força de trabalho aceitam como responsabilidade pessoal assegurar que todas as práticas sejam implementadas 
efetivamente. Assim, eles aceitam como uma responsabilidade primária da sua posição a tarefa de crescimento e desenvolvimento do seu pessoal. Quando as pessoas levam a sério às responsabilidades da sua força de trabalho, elas começam a desenvolver métodos repetíveis para executar atividades específicas, como entrevistar ou estabelecer critérios de desempenho. Os individuos notarão maior consistência no desempenho de funções da força de trabalho dentro do seu grupo, embora gerentes ou grupos diferentes possam ter variações individuais nos métodos específicos que eles usam.

O esforço para implementar melhores práticas de força de trabalho começa quando a administração executiva exige que toda a organização mellore constantemente o conhecimento. habilidades. motivação, e o desempenho de sua força de trabalho. A organização documenta políticas e desenvolve práticas de força de trabalho básicas que as unidades implementarão. Unidades desenvolvem planos para satisfazer as necessidades e responsabilidades da sua força de trabalho. Essas necessidades iniciais estão nas áreas do ambiente de trabalho. comunicação, Staffing. administração de desempenho, treinamento, e compensação. Até essas práticas básicas de força de trabalho serem institucionalizadas, a organização terá dificuldade em adotar práticas mais sofisticadas.

As áreas chave de processo do nível Repetivel estabelecem que a prática básica da força de trabalho atua eliminando problemas de desempenho de trabalho. Abaixo são apresentadas as seis áreas chave de processo do nivel Repetível:

- Ambiente de Trabalho: projetada para estabelecer e manter condições de trabalho que permitam que os indivíduos se concentrem nas suas tarefas, sem distrações desnecessárias ou impróprias. Essa área chave acarreta assegurar que: exista um lugar apropriado; que o ambiente obedeça todas as leis e regulamentos aplicáveis; e que sejam feitas melhorias que aumentarão o desempenho, removendo os empecilhos para esse desempenho, minimizando assim as distrações.

- Comunicação: projetada para estabelecer um ambiente social que sustente uma interação efetiva e assegure que a força de trabalho tenha as habilidades para compartilhar informações e coordenar as suas atividades eficazmente. Para isso deve-se estabelecer mecanismos de comunicação top-down e bottom-up dentro da organização, e assegurar que todos os indivíduos tenham as habilidades de comunicações necessárias para executar e coordenar as suas tarefas, administrar reuniòes e solucionar problemas. 
- Staffing: projetada para estabelecer e usar um processo formal pelo qual a organização recruta, seleciona, e transaciona os novos talentos para atuar nas suas tarefas.

- Administracão de Desempenho: estabelece um critério objetivo de avaliação e acompanhamento do desempenho no trabalho dos individuos e das unidades. Nessa KPA deve-se identificar maneiras de aumentar esse desempenho, gerenciar os problemas relativos ao desempenho e recompensar o desempenho extraordinário.

- Treinamento: projetada para assegurar que todos os individuos tenham as habilidades exigidas para executar suas tarefas. Treinamento envolve identificar as habilidades exigidas para executar tarefas críticas e identificar os treinamentos necessários dentro de cada unidade, assegurando que a necessidade de treinamento seja recebida.

- Compensação: projetada para proporcionar a todos os individuos remuneração e benefícios baseados na sua contribuição à organização. Compensação inclui desenvolver uma estratégia de compensação, desenvolver um plano para administrar a compensação, e fazer ajustes periódicos na compensação baseados no desempenho.

\subsubsection{Nivel 3: O Nivel Definido}

Organizações no nível Repetivel achan que embora elas estejam executando práticas básica de força de trabalho há inconsistência en como estas práticas são executadas através das unidades. A organização não está aproveitando as oportunidades para unificar suas melhores práticas de força de trabalho, porque não identificou o conhecimento comum e as habilidades que precisa para suas unidades e as melhores práticas a serem usadas pelos desenvolvedores. A organização é motivada a alcançar o nível Definido para ganhar uma vantagem competitiva estratégica em suas competências essenciais.

No nível Definido, a organização começa a adaptar suas práticas de força de trabalho para a natureza específica de seu negócio. Analisando as habilidades requeridas por sua força de trabalho $\mathrm{e}$ as funções empresariais que elas executam, identificam na organização as competências essenciais que necessitam para executar seu negócio. A organização adapta então sua prática de força de trabalho para desenvolver o conhecimento específico e habilidades que compõem essas competências essenciais. A organização identifica melhores práticas em suas próprias atividades de força de trabalho ou em outras organizações e as unifica como base para adaptar suas práticas. 
A organização analisa seus processos empresariais para determinar as competências essenciais envolvidas em seu trabalho e o conhecimento e habilidades que constituem essas competências. A organização então, cria estratégias e planos para desenvolver essas competências pela organização. Um programa é sistematicamente definido para as competências essenciais em desenvolvimento. e planejamento individual de carreiras e estratégias são desenvolvidas para apoiar o desenvolvimento de competências para cada indivíduo. A organização administra sua prática de força de trabalho desenvolvendo e recompensando o crescimento em suas competências essenciais e aplicando para melhorar o desempenho.

Uma cultura organizacional comum pode se desenvolver no nível Definido porque a organização preocupa-se em desenvolver e recompensar um conjunto de competências essenciais. Esta cultura foca a importância em crescer as capacidades da organização em suas competências essenciais, e toda a força de trabalho começa a compartilhar responsabilidades por esse crescimento. Tal cultura é reforçada quando são adaptadas práticas de força de trabalho de encorajamento e recompensa ao crescimento nás competências essenciais da organização. Essa cultura pode crescer estabelecendo-se um ambiente participativo onde os individuos e os grupos são envolvidos em decisões que dizem respeito a seu trabalho.

A capacidade da força de trabalho das organizações no nível Definido está baseada em ter uma força de trabalho que possua o conhecimento básico e as habilidades para executar o núcleo de funções empresariais da organização. Conhecimento e habilidades nas competências essenciais da organização são distribuídos mais uniformemente. A organização melhora sua habilidade para predizer o desempenho de suas atividades de trabalho, pois sabe o nível de conhecimento e habilidades disponíveis em sua força de trabalho. Também, estabelece uma fundação na qual o desenvolvimento contínuo de conhecimento e habilidades pode ser construido.

As áreas chave de processo no nivel Definido são direcionadas a questões organizacionais. A organização identifica suas competências essenciais e a execução das práticas da força de trabalho, definidas pelo ambiente empresarial para enriquecer suas capacidades. A organização direciona as atividades da sua força de trabalho para o desenvolvimento e a gratificação das suas competências essenciais. São estabelecidas atividades de plano de carreira e é criada uma cultura de participação. Abaixo são apresentadas as seis áreas chave de processo do nivel Definido: 
- Análises de Conhecimento e Habilidades: projetada para identificar o conhecimento e as habilidades necessárias para desempenhar os processos de negócios, possibilitando que eles sejam desenvolvidos e empregados como uma base para as práticas da força de trabalho. Nessa área, acarreta-se: identificar os processos empresariais nos quais a organização deve manter competências. desenvolvendo-se os perfis do conhecimento e das habilidades; manter um inventário dos perfis do conhecimento e das habilidades; e identificar necessidades futuras de conhecimento e de habilidades.

- Planejamento da Força de trabalho: projetada para coordenar atividades atuais da força de trabalho com as necessidades empresariais futuras em níveis de unidade e organizacionais. Planejamento da Força de trabalho acarreta desenvolver um plano estratégico da força de trabalho que estabeleça os objetivos organizacionais para o desenvolvimento de competências e das atividades de força de trabalho, e o desenvolvimento de planos para guiar as atividades da força de trabalho em cada unidade.

- Desenvolvimento de Competência: projetada para o aumento constante da capacidade da força de trabalho na execução das suas tarefas e responsabilidades. As competências essenciais identificadas em Análises de Conhecimento e Habilidades e no Planejamento da Força de Trabalho provêem a fundação do desenvolvimento e do programa de treinamento da organização. As atividades de desenvolvimento são projetadas para elevar o nível de conhecimento e habilidade da organização e antecipar competências essenciais. No Desenvolvimento de Competências acarreta-se estabelecer treinamentos e outros programas de desenvolvimento para cada uma das competências essenciais da organização.

- Desenvolvimento de Carreira: projetada para assegurar que todos os indivíduos estejam motivados e que sejam providas oportunidades para desenvolver habilidades novas que aumentem as suas capacidades em alcançar os objetivos da carreira. Desenvolvimento de carreira inclui discussões de opções de carreira com cada indivíduo e desenvolvimento de um plano de desenvolvimento pessoal, localizando o seu progresso, identificando oportunidades de treinamento e fazendo tarefas que aumentem os objetivos de carreira.

- Práticas Baseadas em Competência: projetada para assegurar que todas as práticas da força de trabalho sejam em parte baseadas no desenvolvimento dos conhecimentos e das habilidades da força de trabalho. Práticas Baseadas em Competências acarretam recrutamentos, baseados em métodos de seleção de acordo com as necessidades de conhecimento e de habilidades e baseadas em compensação de acordo com o crescimento do conhecimento e das 
habilidades. Os métodos avaliam o conhecimento e as habilidades dos candidatos quanto ao desempenho do trabalho nas tarefas e metas nomeadas à posição.

- Cultura de Participação: assegura um fluxo de informação dentro da organização. para incorporar o conhecimento dos indivíduos nos processos de tomada de decisão, ganhando o seu apoio nos compromissos. O estabelecimento de uma cultura de participação é a fundação para a construção de times de alto desempenho. Cultura de Participação acarreta estabelecer comunicações efetivas entre todos os níveis da organização e buscar introduzir e envolver os indivíduos nas decisões e compromissos.

\subsubsection{Nivel 4: O Nível Gerenciado}

Organizações no nível Definido estabelecem a fundação para melhorar a sua força de trabalho continuamente. No nível Gerenciado, as organizações começam a administrar seu núcleo de competências como uma vantagem estratégica e estabelecem objetivos para $\circ$ crescimento nessas competências e para o alinhamento de desempenho do indivíduo. times. unidades, e niveis organizacionais. Essas medidas estabelecem a fundação quantitativa para avaliar tendências na capacidade da força de trabalho da organização. $\mathrm{Na}$ sequiência, busca maximizar a efetividade em aplicar essas competências desenvolvendo times que integrem conhecimento complementar e habilidades.

No nível Gerenciado, times de alto desempenho, compostos das pessoas com conhecimento e habilidades complementares são desenvolvidos em condições que apóiem a sua funcionalidade. Atividades de construção de times são realizadas para melhorar a efetividade desses times. Aplicando as práticas de times, uma força de trabalho é integrada para apoiar o desenvolvimento e o desempenho do time. Além disso, são criados mentores individuais e para os times. Mentores usam a sua experiência para prover apoio pessoal, direção, e um pouco de desenvolvimento de habilidade. Mentores também fornecem um outro modo de reter e disseminar lições aprendidas pela organização.

O crescimento organizacional em cada competência essencial da organização é gerenciado quantitativamente. Os dados são analisados com base nas competências essenciais da organização para determinar tendências e capacidades, essas tendências de competência avaliam a efetividade das práticas da força de trabalho relacionadas à competência. Além disso, são colecionados dados de desempenho que são analisados para tendências no alinhamento do 
desempenho do individuo, unidade, e níveis organizacionais. Essas tendências são usadas para avaliar a efetividade das práticas que a força de trabalho desempenhou, sendo localizadas no conjunto de objetivos estratégicos e nos planos da força de trabalho.

A capacidade da força de trabalho das organizações no Nível 4 é previsivel porque é quantitativamente conhecida. A organização também desenvolveu um mecanismo para desdobrar suas competências efetivamente com alto desempenho e competências baseada em times. Podem ser preditas tendências futuras em capacidade de força de trabalho e desempenho porque a capacidade prática para melhorar o conhecimento e habilidades da força de trabalho é quantitativamente conhecida. Esse nivel de capacidade da força de trabalho proporciona para a organização um indicador importante de tendências em sua capacidade empresarial.

As áreas chave de processo do nível Gerenciado enfocam a construção de times baseados em competências e o estabelecimento de uma compreensão quantitativa das tendências no desenvolvimento do conhecimento e habilidades e no alinhamento de desempenho por diferentes niveis da organização. A análise das cinco áreas chave de processo desse nível é altamente interdependente. A seguir, são descritas as áreas chaves de processo do nivel Gerenciado:

- Mentoring: usa a experiência da força de trabalho da organização para prover apoio individual e diretrizes para outros indivíduos ou grupos. Essas diretrizes acarretam: desenvolvimento de conhecimento e habilidades; melhora de desempenho; liderança em situações dificeis; e tomada de decisões de carreira. Mentoring acarreta estabelecer objetivos para um programa de Mentoring, projetar atividades de Mentoring para alcançar estes objetivos, selecionar e treinar os mentores apropriados, nomeando os mentores a indivíduos ou grupos, estabelecendo relações de Mentoring, e avaliando a efetividade do programa de Mentoring.

- Construção de Times: projetada para capitalizar oportunidades para a criação de times que maximizam a integração de diversos conhecimentos e habilidades para o desempenho das funções empresariais. Construção de Times acarreta emparelhar os potenciais dos membros do time para o conhecimento e as habilidades exigidas no time, treinando todos os novos membros quanto às habilidades do time, definindo objetivos para o desempenho do time, integrando processos padrões para uso pelo time, e revisando periodicamente o desempenho do time.

- Práticas baseadas em times: integra as práticas da força de trabalho da organização para apoiar o desenvolvimento, motivação e funcionamento dos times. Práticas baseadas em times acarretam assegurar que o ambiente de trabalho apóie funções de time e fixe critérios de desempenho, revisando o desempenho do time, envolvendo os membros do time na execução das 
atividades da força de trabalho, e refletindo os critérios do time em decisões de compensação individual.

- Administração de Competências Organizacionais: projetada para aumentar a capacidade da organização em suas competências essenciais e determinar a efetividade de suas atividades de desenvolvimento de competências alcançando metas de crescimento em competências específicas. Administração de Competência organizacional acarreta: estabelecer metas mensuráveis para o crescimento das competências essenciais da organização; definir e coletar dados pertinentes a eles, analisando o impacto de atividades de desenvolvimento de competência em alcançar estas metas, e usando os resultados para guiar a aplicação e melhoria de atividades de desenvolvimento de competência.

- Alinhamento de Desempenho Organizacional: projetada para aumentar o alinhamento de resultados de desempenho dos individuos, dos times, das unidades, e níveis organizacionais com as metas apropriadas, e para quantitativamente avaliar a efetividade das práticas de força de trabalho em alcançar o alinhamento. Alinhamento de Desempenho organizacional acarreta: fixar metas mensuráveis para alinhar desempenho dos indivíduos, dos times. das unidades, e dos niveis organizacionais; definir, coletar e analisar dados; análises das tendências em relação aos objetivos, agindo em encontros excepcionais, analisando o impacto das práticas relacionadas às pessoas, em alinhamento de desempenho, e informando resultados.

\subsubsection{Nível 5: O Nível Otimizado}

No nivel Otimizado, há um enfoque contínuo em melhorar competências individuais e encontrar modos inovadores para melhorar a motivação e a capacidade da força de trabalho. A organização sustenta o esforço individual para desenvolvimento contínuo das competências pessoais. São fornecidos os treinadores para apoiar o desenvolvimento adicional pessoal ou das competências de time. Dados da efetividade das práticas são usados para identificar as necessidades de práticas de força de trabalho ou tecnologias inovadoras. Práticas e tecnologias inovadoras são avaliadas e as mais promissoras são usadas em tentativas exploratórias. As inovações mais prósperas em uso são, então, transferidas para toda a organização.

A capacidade da força de trabalho em organizações do nível Otimizado está melhorando continuamente porque elas estão perpetuamente melhorando as suas práticas de força de trabalho. A melhoria acontece tanto por avanços no incremento em sua prática de força de 
trabalho existente, quanto pela adoção de práticas inovadoras e métodos que podem ter um impacto dramático. A cultura criada em uma organização otimizada é aquela na qual todos os membros da força de trabalho estão se esforçando para melhorar eles próprios, o seu time, e o conhecimento da sua unidade, habilidades, e motivação para melhorar o desempenho global da organização. As práticas da força de trabalho são afiadas para criar uma cultura de excelência de desempenho.

As áreas chave de processos do nivel Otimizado envolvem questões endereçadas a melhorias contínuas de capacidades da organização e dos indivíduos. São realizadas melhorias continuas das competências da organização e dos indivíduos. Os métodos da organização para desenvolvimento de suas competências e de desempenhos são disponibilizados a partir de feedbacks quantitativos e adoção de práticas inovadoras e tecnológicas. A seguir são descritas as três áreas chave de processo para Nivel 5 :

- Desenvolvimento de Competência Pessoal: projetada para prover uma fundação para o auto desenvolvimento profissional. Desenvolvimento de Competência Pessoal consiste em um programa voluntário para melhoria contínua dos processos de trabalho individuais. Este programa acarreta: desenvolvimento de metas e planos para atividades de trabalho pessoais; estabelecimento e aplicação de processos pessoais definidos; medição e eficácia desses processos pessoais e implementação de melhorias para eles. A organização faz ajustes na aplicação da força de trabalho para apoiar o desenvolvimento da competência pessoal. São reconhecidas as melhorias nos processos de trabalho individual.

- Coaching: projetada para prover ajuda especializada para aumentar o desempenho de indivíduos ou de times. Os Coachs se encarregam de relacionamentos fechados com individuos ou times para direcionar o desenvolvimento de habilidades que melhoram o desempenho. Coaching acarreta: selecionar os treinadores apropriados e analisar os dados de desempenho pessoal ou de time; prover diretrizes aos métodos para melhoria do desempenho; e avaliar o progresso direcionado as metas para melhoria de desempenho.

- Inovacão Contínua da Força de Traballoo: projetada para identificar e avaliar melhorias das práticas da força de trabalho e tecnológicas, e implementar a mais promissora por toda a organização. Inovação Contínua de Força de trabalho acarreta: estabelecer um mecanismo para propor melhorias das atividades da força de trabalho, identificar necessidades para novas práticas; avaliar e inspecionar práticas e tecnologias inovadoras; conduzir tentativas exploratórias de novas práticas e tecnologias; e implementar a mais benéfica para a organização. 


\subsection{Objetivos do P-CMM}

Pode-se resumir os objetivos do P-CMM em quatro temas:

1. Desenvolvimento de Capacidades: $\mathrm{O}$ esforço para desenvolver as capacidades das pessoas na organização começa no nível Repetivel identificando o treinamento imediato necessário às pessoas em cada unidade (Treinando). Capacidades de comunicação oral e escrita são melhoradas por treinamento (Comunicação). No nível Definido a organização é levada a olhar sistematicamente o conhecimento e as habilidades exigidas para executar os processos empresariais da organização (Conhecimento e Análise de Habilidades) e identifica os núcleos de competências. A organização também estabelece um programa de desenvolvimento amplamente organizado para essas competências (Desenvolvimento de competência). No nível Gerenciado. mentores são providenciados para guiar os indivíduos ou times no próprio desenvolvimento (Mentoring). Finalmente, no nível Otimizado, pessoas podem iniciar um programa individual para desenvolver as suas Competências (Desenvolvimento de competência Pessoal), e serão fornecidos os treinadores para esses que querem ajuda (Treinando). O desenvolvimento de maturidade da força de trabalho inicia identificando-se as necessidades correntes e realizando o treinamento necessário dentro de cada unidade, prossegue formando os indivíduos nas competências essenciais desenvolvidas pela organização, e então retorna o foco nos indivíduos para que eles estabeleçam o seu próprio prograna de desenvolvimento profissional.

2. Construção de times e cultura: $\mathrm{O}$ esforço para melhorar os modos como as pessoas são organizadas e interagem na organização começa no nivel Repetível, com um enfoque em melhorar tanto a comunicação forrnal quanto a interpessoal dentro da organização (Comunicação). No nível Definido a organização desenvolve uma cultura de participação aumentando o envolvimento da força de trabalho em decisões que afetam o seu trabalho (Cultura Participativa). No nível Gerenciado a organização começa a construir alto desempenho e times baseados em competência o que lhes proporciona um nivel apropriado de autonomia (Construindo Times). No nível Otimizado a organização procura continuamente modos inovadores para melhorar a cultura ou o funcionamento dos times (Inovação Contínua da Força de trabalho). A. Tendência de maturidade construindo times e cultura começa estabelecendo 
habilidades de comunicação básicas, cresce desenvolvendo uma cultura de participação, e continua em construir times formais e melhorias contínuas das capacidades do time.

3. Motivação e administração de desempenho: $\mathrm{O}$ enfoque em motivação e desempenho começa no nível Repetível com o estabelecimento de um ambiente que tenha recursos adequados e não impeça ou distraia o desenppenho no traballıo (Ambiente de Trabalho). Discussões sobre como melhorar o desempenho são periodicaınente empregadas, desempenho inaceitável é Gerenciado, e reconhecimento é provido para o desempenho excelente (Administração de desempenho). A compensação básica e o sistema de benefícios são definidos nesse nível. e sua administração é amarrada, parcialmente pelo desempenho (Compensação). No nível Definido as práticas de força de trabalho estabelecidas no nível Repetível são adaptadas para motivar o desenvolvimento das competências essenciais (Práticas Baseadas em Competência). A organização também estabelece um conjunto de oportunidades graduadas de carreira projetada para motivar e recompensar as pessoas por desenvolver habilidades adicionais (Desenvolvimento de Carreira). No nível Gerenciado as práticas da força de trabalho são novamente adaptadas. agora para uso com Times baseados em Competência (Práticas Baseadas em Times). A organização também fixa e rastreia objetivos para o alinhamento de desempenho do indivíduo, times, unidades, e niveis organizacionais (Alinhamento de Desempenho Organizacional). No nivel Otimizado a organização procura por práticas de força de trabalho que sejam inovadoras e tecnologias que possam. mais adiante motivar ou aumentar o desenvolvimento de competências ou desempenho no trabalho (Inovação de Força de trabalho Contínua). A tendência de maturidade em motivar e administrar o desempenho começa ao se estabelecer administração básica de desempenho e práticas de compensação, então melhora essas práticas adaptando para o desenvolvimento de competência e construção de times, olhando então para fontes constantes de inovação.

4. Formação da força de trabalho: O esforço para formar a força de trabalho e para se. encontrar necessidades empresariais começa no nível Repetível estabelecendo-se práticas básicas para recrutar e selecionar os candidatos de trabalho, e orientar as novas pessoas nas tarefas (Staffing). No nível Definido a organização começa a desenvolver estratégias, planejando e assegurando que tenham as competências essenciais, as necessidades de conhecimento corrente e as demandas de negócios futuros (Planejamento da Força de trabalho). No nível Gerenciado a organização fixa e localiza alvos para o desenvolvimento de conhecimento e habilidade em cada uma de suas competências essenciais (Administração de Competência Organizacional). No Nível 
Otimizado as procuras da organização são para práticas ou tecnologias inovadoras para ajudar a formar sua força de trabalho (Inovação Contínua da Força de trabalho). A tendência de maturidade na formação da força de trabalho começa com o estabelecimento das práticas básicas de pessoal, cresce em planos de desenvolvimento para a força de trabalho, fixa e localiza objetivos para competências na força de trabalho, e então localiza fontes constantes de inovação.

A implementação de áreas chave de processos em um nível pode ser vista como 0 . estabelecimento de uma base para práticas e capacidades para o próximo nível, sendo mapeadas nos quatro temas, conforme tabela 2-2.

\begin{tabular}{|c|c|c|c|c|}
\hline $\begin{array}{c}\text { Nível de } \\
\text { Maturidade }\end{array}$ & 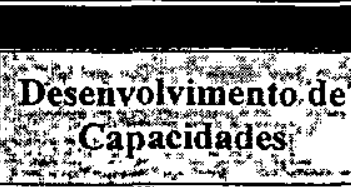 & 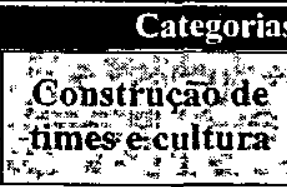 & $\begin{array}{l}\text { de processo } \\
\text { Motivaçãoses } \\
\text { administraçád } \\
\text { rdesempenho }\end{array}$ & 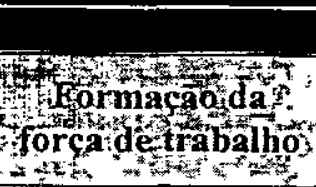 \\
\hline 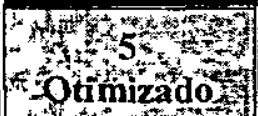 & $\begin{array}{c}\text { Treinando } \\
\text { Desenvolvimento de } \\
\text { Comnetência Pessol }\end{array}$ & Inova & ăo Continua da Força d & Trabalho \\
\hline 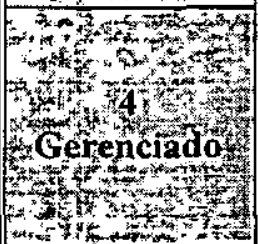 & Mentoring & $\begin{array}{c}\text { Construção de } \\
\text { Times }\end{array}$ & $\begin{array}{c}\text { Alinhamento de } \\
\text { Desempenho } \\
\text { Organizacional, } \\
\text { Práticas baseadas em } \\
\text { times }\end{array}$ & $\begin{array}{l}\text { Administração de } \\
\text { Competências } \\
\text { Organizacionais }\end{array}$ \\
\hline 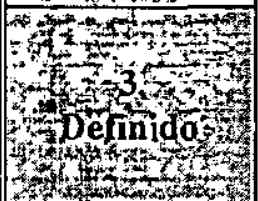 & $\begin{array}{l}\text { Desenvolvimento de } \\
\text { Competência } \\
\text { Conhecimento e } \\
\text { Análise de Habilidades }\end{array}$ & $\begin{array}{l}\text { Cultura de } \\
\text { Participação }\end{array}$ & $\begin{array}{c}\text { Práticas Baseadas em } \\
\text { Competência } \\
\text { Desenvolvimento de } \\
\text { Carreira }\end{array}$ & $\begin{array}{l}\text { Planejamento da } \\
\text { Força de Trabalho }\end{array}$ \\
\hline 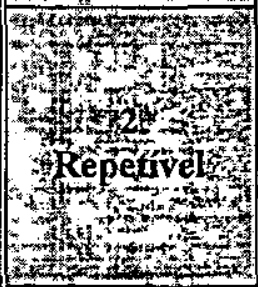 & $\begin{array}{l}\text { Treinamento } \\
\text { Comunicação }\end{array}$ & Comunicação & $\begin{array}{c}\text { Compensação } \\
\text { Administração de } \\
\text { Desempenho } \\
\text { Ambiente de } \\
\text { Trabalho }\end{array}$ & Staffing \\
\hline Tnicil & & & & \\
\hline
\end{tabular}

Tabela 2-1: Temas do P-CMM

A existência desses temas implica que melhorias em algumas áreas não estão restritas a uma única área chave de processo, mas incluem um conjunto integrado de práticas de algumas áreas de processos. 


\subsection{Considerações Finais}

Neste capítulo mostrou-se como o People Capability Maturity Model pode ajudar as organizações a atingir um nivel de excelência na produção de software resolvendo-se o problema da força de trabalho imatura e desorientada que não focaliza o auto desenvolvimento e 0 aprendizado contínuo. Através de varias visões, procurou-se mostrar como o P-CMM alinha esse desenvolvimento e esse aprendizado ao desenvolvimento da organização em suas competências essenciais. através de um processo evolutivo. Dessa maneira. aumenta-se a maturidade da organização na produção de software, através de seu componente mais complexo, as pessoas.

No capítulo seguinte, expande-se us conceitos do P-CMM de motivação e comprometimento das pessoas, através de aspectos encontrados na teoria administrativa. que influenciam a força de trabalho durante um processo de mudança e na busca do aprendizado contínuo. 


\section{MUDANÇA ORGANIZACIONAL}

\subsection{Considerações iniciais}

O P-CMM é um modelo totalmente voltado para as pessoas que compõe o processo de software. mas é um modelo muito novo que tem muito a evoluir. Em contrapartida as teorias administrativas vêm evoluindo seu foco de estudo para as pessoas e a inter-relação dessas com todo o processo de uma organização, muito antes da engenharia de software, e até mesmo da própria industria de software, ser criada. Baseado nisso, neste capítulo são abordados os fatores que envolvem as pessoas durante os processos de mudança, de maneira genérica, desvinculado da área de software. É mostrado como a administração vê o processo de mudança e a influência da cultura da organização nesse processo. Na seqüência, são tratados os fatores que influenciam as pessoas e que precisam ser gerenciados durante um processo de mudança.

\subsection{O Sistema Organizacional e o Processo de Mudança}

Toda empresa pode ser vista como um conjunto de recursos organizados para interagirem com o ambiente, transformando insumos em produtos de valor agregado, ou seja, as empresas são sistemas abertos. Isso significa que as áreas, os componentes e tudo mais que compõe uma empresa está interligado, interagindo e tentando manter-se em equilíbrio.

A idéia de que estrutura organizacional de uma empresa é um sistema é defendida por Nadler (1992, p.43), que propõe um modelo formado por quatro grandes partes: estrutura e processos informais, trabalho, pessoal e disposições organizacionais formais.

Nessa estrutura um processo de mudança organizacional envolveria mudar as quatro grandes partes de forma a manter o equilíbrio e não desestruturar a empresa ou ocasionar novos 
problemas. Afinal a idéia de mudar uma organização é obviamente para melhorá-la e torná-la mais produtiva e eficiente.

No entanto, a visualização do todo em detalhes suficientes para elaborar diretrizes de mudança é uma atividade extremamente complexa e com certeza esconde detalhes importantes. Por essa razão, normalmente, se estuda a mudança em cada uma das partes da empresa individualmente. Esse tipo de estudo é importante, pois foca os detalhes pertinente a um único setor, área, ou componente, no entanto é importante sempre estar atento aos seus efeitos nas outras áreas.

É lógico. e talvez até mais importante, considerar que a reciproca também é verdadeira. Ao se pensar em mudar um setor, área, ou componente, deve-se estar atento à possibilidade de fazêlo através da mudança em outro ponto.

Os processos de mudança são muitos e variam de acordo com a visão que cada autor tem da estrutura organizacional. Motta (1999) analisa diversas formas de mudança, como por exemplo: mudança estratégica, estrutural, tecnológica, humana, cultural e política. Mesmo analisando-as separadamente, o autor deixa claro que partilha da idéia de empresa como sistema e como tal. a mudança organizacional é a soma de todas essas mudanças.

Normalmente foca-se a mudança em uma única área com o intuito de se atingir um objetivo específico, por exemplo, uma mudança estrutural objetiva prioritariamente a adequação da autoridade formal tentando resolver problemas de redistribuição de deveres e direitos. Esse tipo de mudança tem como proposição principal redefinir e flexibilizar os limites formais para o comportamento administrativo (Motta).

Mas como já foi analisado a organização é um sistema e ao flexibilizar-se os limites do comportamento administrativo, pode-se criar conflitos de interesse ou ameaças à singularidade e aos padrões de identidade organizacional o que cria a necessidade de mudanças políticas e culturais.

Neste estudo o interesse é nos fatores humanos que interferem no processo de mudança, pois o que se quer é saber como os analistas, programadores e engenheiros de software envolvidos na melhoria do processo podem criar barreiras que interfiram nesse processo de mudança. Diante disso neste capítulo o processo de mudança é focado na mudança cultural de uma organização. 


\subsection{A Mudança Cultural}

Quando falamos de mudanças em una organização, a alteração nos seus padrões culturais pode acontecer de duas maneiras: mudança revolucionária - na qual os novos valores incorporados à organização são antagônicos aos anteriores, gerando um processo radical de destruição dos elementos simbólicos e de redefinição completa das práticas organizacionais - e mudança gradual - quando os novos valores propostos são complementares aos existentes. ampliando o leque de alternativas para a solução de problemas.

As mudanças graduais parecem ser mais adequadas para o processo de desenvolvimento de uma cultura de aprendizagem, pois à medida que os novos valores são incorporados de maneira menos traumática, gerando menor ansiedade, as pessoas se predispõem mais facilmente a procurar novas alternativas ou soluções, alén de incorporar uma dinâmica da aprendizagem permanente.

Já certos processos de mudanças muito radicais, como, por exemplo, determinados processos de reengenharia podem gerar o medo da instabilidade, acompanhado de insegurança, e o desejo de não mais mudar.

Além da velocidade como a mudança acontece, o comportamento individual das pessoas envolvidas no processo pode resultar em barreiras a mudança. De acordo com Siddall (1997) as pessoas reagem às mudanças inicialmente com surpresa e por fim com aceitação, mas entre esses dois estágios sentimentos como raiva e medo são comuns, levando algumas pessoas a pararem em um desses sentimentos e não acompanhar a mudança. Além disso, a personalidade das pessoas e a forma como normalmente reagem a um processo de aprendizagem influência na resistência gerada por essas pessoas à mudança. A personalidade das pessoas pode fazer com que queiram entender detalhes da mudança ou ver resultados antes de participar e a forma como iniciam o aprendizado pode torná-las pessoas interessadas na mudança ou meras espectadores no início. Esses detalhes diferenciam os envolvidos na mudança, em colaboradores e resistentes, deixando entre eles, os indecisos.

Entender a resistência e as barreiras à mudança, assim como seus caminhos e fontes, são importantes para se administrar o ambiente organizacional com eficiência e conseqüentemente agilizar as mudanças. O gerente de projeto que pretende introduzir novas técnicas e tecnologias deve antes preparar o ambiente para receber essas mudanças, "um ambiente propicio a mudança 
engloba fatores como gestão participativa, envolvimento de funcionários, sistemas de trabalho. comunicação, ambiente físico, clima organizacional, formas de trabalho, relacionamentos, enfim. envolve um conjunto de variáveis que se relacionam diretamente aos recursos humanos da empresa e influenciam a organização e execução do trabalho" Bittencourt (1996).

A velocidade com que as mudanças irão ocorrer está diretamente ligada ao grau de assimilação das pessoas a essa mudança. por isso, "a necessidade de comprometimento e participação das pessoas será de fundamental importância na transição para um novo ambiente de trabalho... Deverá ser dada uma grande atenção ao treinamento, pois o processo de mudança é lento e gradual, não somente com as pessoas em geral, mas também com as gerências" (Bio. 1985).

Independentemente da origem dos fatores que afetam a resistência das pessoas à mudança, essa deve ser gerenciada toda hora. todos os dias. e "gerenciar resistência demanda habilidades que vão ser requeridas cada dia como resolução de conflitos, negociação, resolução de problemas e gerenciamento de reuniões" (Siddall, 1997). Dessa forma, compreender as fontes de resistência e conseqüentemente saber as ações corretas a serem tomadas no gerenciamento dessas resistências é, sem dúvida, uma maneira de agilizar essas mudanças.

Entendida as origens e formas da resistência, pode-se definir uma estratégia de gerenciamento, que deve necessariamente contar com o comprometimento da alta gerência. Essa estratégia deve contar com ferramentas chamadas agentes facilitadores, que são elementos que procuram minimizam a resistência à mudança através do envolvimento e comprometimento de todas as pessoas da organização. Nesse sentido um agente facilitador seria toda e qualquer estratégia que atenua o impacto da mudança. minimizando os conflitos, a resistência e as dificuldades na implantação de programas de melhoria de competitividade.

O que pode ser observado, é que para mudar algo em uma empresa de maneira rápida, não importa qual a alteração a ser feita, tanto a introdução de uma nova tecnologia como a adoção de um novo processo, deve-se começar pelas pessoas envolvidas. Para mudar as pessoas, tem-se que entender a cultura existente por traz de suas atitudes e comportamentos. 


\subsection{Cultura Organizacional}

Quando se pensa na cultura de um povo. seja ela a população de um país, de um estado ou de uma cidade, pensa-se nas características, nos hábitos, no modo agir e pensar, pensa-se em sua dança. sua música, seu modo alimentar típico e até no seu modo de pensar. Enfím quando se refere à cultura de um grupo, fala-se naquilo que os diferencia. naquilo que os torna um grupo. Da mesma forma, uma organização, seja ela uma empresa ou uma unidade de um departamento possui características culturais próprias. Dessa forma a cultura organizacional, pode ser entendida como um conjunto de valores tangiveis e intangíveis, que definem e caracterizam aquele grupo em particular.

"Cultura organizacional é o conjunto de pressupostos básicos (basic assumptions) que um grupo inventou, descobriu ou desenvolveu ao aprender como lidar com os problemas de adaptação externa e integração interna e que funcionam bem o suficiente para serem considerados válidos e ensinados a novos membros como forma correta de perceber, pensar $e$ sentir, em relação a esses problemas" (Schein, 1986).

A preocupação com a cultura organizacional vem despertando a atenção de pesquisadores desde longa data, Fleury (1989) destaca que "os obstáculos enfrentados por administradores/consultores para implantar processos de mudanças, tecnicamente bem justificados. mas que não conseguem decolar, indicam a necessidade de incorporar a questão da cultura organizacional". Dessa forma, se a mudança ou melhoria a ser implantada é justificável, a utilidade da cultura está na compreensão das dificuldades a serem enfrentadas e a necessidade do seu estudo pelo fato que assim, obtém-se uma indicação mais precisa na criação de facilitadores de mudança.

A cultura organizacional, porém, possui também uma outra funcionalidade que motiva o seu estudo quando o contexto é gerenciar mudanças, ela "serve a interesses específicos, fornecendo um guarda chuva aos atos do grupo dominante" (Melo, 1991). Portanto o domínio e a manipulação correta dos fatores que fazem parte da cultura organizacional é uma das principais ferramentas no processo de facilitar e agilizar as mudanças.

É claro que a cultura não é imposta ou simplesmente criada, considera-se sim, "que grande parte da cultura existente numa organização é destinada a desenvolver certos padrões desejáveis de comportamento, mas não deixando de considerar que, mesmo em níveis e escalas 
diferentes. os empregados influenciam a produção dessa cultura" (Melo, 1991). Logo; apèsar de poderosa. essa não é uma ferramenta trivial, é necessário saber qual o padrão de comportamento que se deseja estudar os aspectos culturais, para entender as atitudes aparentemente incoerentes e para saber quais atitudes devem ser estimuladas.

A cultura de uma organização pode ser aprendida em vários níveis (Fleury, 1989):

$\dot{\Rightarrow}$ Nível dos artefatos visíveis, representado pelo ambiente construido da organização. arquitetura, lay out, a maneira das pessoas se vestirem, padrões de comportamento visíveis, documentos públicos. Esse nível de análise, segundo Schein. é muito enganador, porque os dados são fáceis de obter, mas dificeis de intèrpretár. É possivel se descrever como um grupo constrói o seu ambiente e quais os padrões de comportamento discerniveis entre os seus membros. mas freqüentemente não se consegue compreender a lógica subjacente ao comportamento do grupo.

$\Rightarrow$ Nível dos valores que governam o comportamento das pessoas, que săo dificeis de se observar diretamente. Para identificá-los é preciso entrevistar os membros-chave de uma organização ou realizar a análise de conteưdo de documentos formais da organização. Entretanto, ao identificar esses valores, observa-se que eles geralmente representam apenas os valores manifestos da cultura. Isto é, eles expressam o que as pessoàs reportam sẹr a razão de seu comporțamento, o que na maioria das vezẹs șão idealizações ou racionalizações. As razões subjacentes ao seu comportamentc permanecem, entretanto, escondidas ou inconscientes.

$\Rightarrow$ Nível dos pressupostos inconscientes que são aqueles pressupostos que determina como os membros de um grupo percebem, pensam e sentem. Na medida em que cert valores compartilhados pelo grupo conduzem a determinados comportamentos-e es eomportamentos : se mostram adequados para solucionar problemas gradualmente transformado em pressupostos inconscientes, sobre como as cc realmente são.

Independente do nivel que se queira identificar, a pesquisa da cultura em uma organização, também segundo Fleury, deve passar pelo histórico da organização, pelo processo de socialização de novos membros, as políticas de RH, os processos de comunicação e a organização do processo de trabalho. 
Dessas categorias vale destacar as duas. últimas, que além de indicarem a cultura que permeia a organização, podem ser usadas como catalisadores da mudança, ou seja, agentes facilitadores. Isso por que o processo de comunicação "constitui um dos elementos essenciais no processo de criação, transmissão e cristalização do universo simbólico de uma organização... e a análise da organização do processo de trabalho. em sua componente tecnológica e em sua componente social. como forma de gestão da força de trabalho possibilita a identificação das categorias presentes na relação de trabalho", (Fleury, 1989).

Devido à amplitude de influência da cultura organizacional, as propostas de se aprender a cultura de uma organização, vão desde as mais simplistas, baseadas no diagnóstico de clima (pretendem apreender os padrões culturais de uma organização a partir da somatória de opiniões e percepções de seus membros), passando pela do clínico ou terapeuta (que ocorre quando a demanda parte da própria organização), até as mais elaboradas que procuram assumir a postura do antropólogo (procura agir ora como observador, ora como observador participante questionando a respeito do significado do universo simbólico das organizações).

Pesquisar a cultura organizacional, mapeando e entendendo seus preceitos é extremamente complexo e demorado não importa a postura adotada, o fundamental é estar consciente de sua importância, analisar o ambiente e diante das possibilidades saber qual caminho adotar.

\subsection{Aspectos Motivacionais}

Um dos aspectos envolvidos no processo de mudança e diretamente relacionado à necessidade de entender a cultura organizacional, são os envolvidos na motivação das pessoas. Motivar a equipe é uma das expectativas que a organização tem quanto aos seus gerentes de projeto, o problema é que "muitos administradores percebem a motivação de forma simplista, visualizando-a como se fosse um ingrediente meramente racional, dependente de fatores estruturais (remuneração, beneficios, status social, auto-imagem etc.), e pudesse ser negociado entre gerência e empregados da empresa. A motivação é, na verdade, um processo contínuo, envolvendo elementos psicológicos, individuais e ambientais, conscientes e inconscientes, que desempenha papel muito importante no comportamento das pessoas" (Castro, 1994, pag34). 
Essas observações quanto à motivação da força de trabalho vem desde a Teoria das Relações Humanas, onde se constatou "a existência de certas necessidades humanas fundamentais. Verificou-se que o comportamento humano é determinado por causas que, às vezes, escapam ao próprio entendimento e controle do homem. Essas causas se chamam necessidades ou motivos: são forças conscientes ou inconscientes que levam o indivíduo a um determinado comportamento".(Chiavenato, 1993, pag 165).

O que se tem então é um ciclo motivacional onde o organismo humano permanece em estado de equilíbrio psicológico, até que um estímulo o rompa e crie uma necessidade. Essa necessidade provoca um estado de tensão em substituição ao anterior estado de equilibrio. A tensão conduz a um comportamento ou ação capazes de atingir alguma forma de satisfação daquela necessidade. Se satisfeita a necessidade, o organismo retorna ao seu estado de equilíbrio inicial, até que outro estímulo sobrevenha. (Chiavenato, 1993).

Para motivar as pessoas a mudar, o ciclo motivacional deve acompanhar o processo de mudança, ou seja, a cada fase da mudança os fatores ambientais e individuais e as expectativas conscientes e inconscientes são diferentes o que torna necessário estratégias diferenciadas de motivação. Logo é importante entender o comportamento humano durante o processo de mudança. Esse processo psicológico passa pelas seguintes fases:

$\Rightarrow$ "Negar a mudança.

$\Rightarrow$ Reagir emocionalmente à mudança.

$\Rightarrow$ Cair em introspecção.

$\Rightarrow$ Negociar.

$\Rightarrow$ Resignar-se ou engajar-se no processo de mudança" (Bio, 1985).

Associado a esse comportamento está à hierarquia de necessidades básicas do ser ımano, proposta por A. H. Maslow, onde "as pessoas são motivadas por cinco tipos distintos de cessidades: fisiológicas, de segurança, de afeto, de estima e de auto-realização. Essas :cessidades estão dispostas segundo uma hierarquia, de acordo com sua capacidade de motivar comportamento" (Hampton, 1992, pag 48). O que se tem então é que o alvo de qualquer necanismo de motivação deve ser as necessidades básicas das pessoas envolvidas, naquele nomento específico do processo de mudança. de acordo com a hierarquia: Auto-realização; Estima; Afeto; Segurança; Fisiológicas. 
Inúmeras teorias sobre motivação têm sido criadas, muitas derivadas das primeiras idéias da Teoria das Relações Humanas. Um desses pensamentos que influenciou e influencia os estudos motivacionais é a teoria da motivação/higiene, de Frederick Herzberg. Onde Motivadores são as fontes de satisfação necessárias para que haja aprimoramento substancial no desempenho do trabalho, que incluem: realização, reconhecimento, o trabalho em si. responsabilidade, avanço e crescimento. Higiene ou manutenção são os fatores necessários para evitar descontentamento, que poderiam fazer o desempenho cair abaixo de um nível aceitável. Esses fatores formam o ambiente de trabalho, são externos ao cargo. e incluem: administração e política da companhia. supervisão, relacionamento com o supervisor, condições de trabalho. salário, relacionamento com os colegas, vida pessoal, relacionamento com os subordinados, 'status`e segurança (Hampton, 1992).

Um modelo motivacional que tenta abordar esses aspectos é o proposto por Castro (1994), onde o comportamento humano é representado como positivo ou negativo de acordo com quatro necessidades que se sucedem em um ciclo motivacional. Sancho Pança-Representando as necessidades fisiológicas; Penélope - Representando as necessidades de segurança; Ulisses Representando as necessidades sociais; Dom Quixote - Representando as necessidades do ego. Esse ciclo motivacional foi associado por Castro ao ciclo de qualidade, mas pode-se interpreta-lo claramente como uma representação do processo de mudança, onde primeiro tem-se a VISÃO da mudança a ser feita, estabelecendo-se as metas e o caminho, depois se segue a IMPLEMENTAÇÃO da mudança, a avaliação ou DISCERNIMENTO, onde uma síntese da: consequiências da mudança é feita e por fim os AJUSTES necessários são feitos.

\begin{tabular}{|c|c|c|c|}
\hline Fase & Personalidade & Positivo & Negativo \\
\hline Visão & Dom Quixote & Idealismo & Fanatismo \\
\hline Implementação & Ulisses & Liderança & Manipulação \\
\hline Discernimento & Sancho Pança & Realismo & Comodismo \\
\hline Ajustes & Penélope & Auto-estima & Isolamento \\
\hline
\end{tabular}

Tabela 3-1: Ciclo VIDA de motivação

Outro aspecto a ser considerado para incentivar as pessoas e criar colaboradores é a "significativa relação entre qualidade e motivação. Especialistas concordam que a qualidade é obtida pelas pessoas e os programas de gestão da qualidade total sempre incluem ações no sentido de motiva-las. Por outro lado, a melhoria da qualidade produziria efeito positivo sobre a motivação e o moral das equipes" (Castro, 1994. pag32). 
Dessa forma o desenvolvimento dos recursos humanos, com intuito de criar colaboradores e conseqüentemente um grupo mais participativo e produtivo, "deve perseguir os seguintes objetivos:

$\Rightarrow \quad$ Introduzir um sistema de gerenciamento baseado na motivação das pessoas.

$\Rightarrow$ Os principais executivos devem promover o comprometimento de todos os componentes da organização.

$\Rightarrow$ Desenvolver a capacidade de pensar em todos os membros da organização

$\Rightarrow$ Desenvolver o espírito de equipe

$\Rightarrow$ Abandonar as estruturas orientadas ao controle e adotar estruturas orientadas ao auto-aprendizado

$\Rightarrow \quad$ Promover a mentalidade do 'poder fazer' "' (Bio, 1985).

\subsection{Agentes facilitadores}

O entendimento da cultura e dos aspectos motivacionais possibilita o uso mais eficiente de ferramentas que facilitam o processo de mudança. Como já foi dito anteriormente. um dos mecanismos que facilitam a mudança e motivam a sua colaboração durante o processo são os agentes facilitadores. Pode-se citar como agentes facilitadores: a comunicação, o treinamento, a recompensa, o benchmarking, o papel exercido pelo líder, o perfil do trabalhador, a redução de niveis hierárquicos, os formadores de opinião, a informalidade e transparência nas relações internas da empresa, a terceirização, o trabalho em equipe e a administração participativa. entre outros.

A comunicação e todo o fluxo de informação dentro de uma organização, por exemplo, pode tanto ser um fator de resistência como um poderoso agente de mudança "considerando os atuais recursos de telecomunicações e processamento de dados, nunca mais será possível tratar a informação como antigamente. A informação não permanecerá como um privilégio de poucos e não mais continuará sendo uma fonte de poder dentro de uma organização. A democratização da informação. tornando-a disponível praticamente para todos, introduzirá drásticas alterações nas relações de poder dentro de uma organização (Bio, 1985). Democratizando-se a informação, qualquer processo de mudança torna-se transparente, possibilitando que todos entendam e 
acẹmpanhem melhor o processo e seus motivos e evitando que as noticias sejam dadas através de boatos, isso tudo agiliza o apoio dos indecisos".

O papel do líder como agente de mudança é outro fator de alta relevância, durante a implantação de qualquer modificação nos processos atuais da organização. É o líder que mantém as pessoas centradas no objetivo da mudança e é nele que as pessoas se apóiam no momento de transpor qualquer obstáculo, principalmente durante uma situação delicada e incerta como é o processo de mudança.

Enquanto a administração exige a estruturação da organização, que ela seja formada com pessoal capacitado e a monitoração das atividades; a liderança vai além dessas funções. inspirando as pessoas a atingir a visão. Os grandes líderes mantêm as pessoas centradas em levar a organização para seu futuro ideal, motivando-as a superar quaisquer obstáculos que existam no caminho. portanto a liderança é algo que se destaca principalmente durante os processos de mudança.

O processo de treinar o 'staff” da organização “deve oferecer oportunidade de aprender habilidades críticas necessárias para desenvolver, implementar e utilizar as habilidades interpessoais, mapear o processo, solucionar problemas e até planejar, independente da posição hierárquica ocupada pelo funcionário. Dessa forma o funcionário é capaz de gerenciar suas prọ́prias ações" (Bitencourt, 1996), tornando o resultado útil para ele e efetivo para a organização. $O$ treinamento focado no desenvolvimento das capacidades das pessoas, não só melhora o desempenho do funcionário em suas tarefas, mas faz com que ele perceba $o$ treinamento como um benefício. Por isso "o treinamento envolve desenvolvimento pessoal, pois enfoca habilidades que serão utilizadas em qualquer situação e não se preocupa apenas com a execução da tarefa em si. Assim, pode-se dizer que existe um enriquecimento do trabalho e uma empregabilidade do operário. Acredita-se que dessa forma, a questão da mudança organizacional possa ser mais bem assimilada, tendo em vista a capacitação funcional e o desenvolvimento pessoal" (Bitencourt, 1996).

No entanto, para que as pessoas utilizem seus conhecimentos e seu treinamento na implantação da mudança, o sistema de recompensa da empresa deve incentivar esse esforço, valorizando a contribuição de todos. O problema da recompensa, conforme lembra Bitencourt, (1996), é que existe uma tendência em relacionar a recompensa com o dinheiro, e em alguns casos essas palavras são sinônimos. Autores como Hronec (1994) e Campos (1992) são resistentes a recompensa monetária por acreditarem que essas dividem os funcionários èm 
ganhadores e perdedores. Isso prejudica a visão de equipe e o trabalho em grupo. Apesar das particularidades do Brasil, que favorecem a recompensa monetária, o programa de recompensa de uma organização deve estar baseado nos fatores motivacionais já descritos anteriormente.

Uma empresa, também pode ter sua cultura como agente facilitador de mudanças. isso acontece quando a cultura organizacional é uma cultura de aprendizagem. "as definições mais comuns de uma organização que aprende enfatizam sua capacidade de adaptação às taxas aceleradas de mudanças, que ocorrem atualmente no mundo. Entretanto, adaptabilidade crescente constitui apenas o primeiro passo no processo de aprendizagem. $O$ desejo de aprender vai mais adiante: é criativo e produtivo“" (Fleury. 1997).

Dessa maneira organizações que criam uma cultura de aprendizagem continua, tem a seu favor um fator de competitividade, agilizando as mudanças e incentivando o processo criativo. Para isso o pensamento sistêmico deve ser encarado como um fundamento para que a empresa torne-se uma organização que aprende, na verdade elas "devem desenvolver cinco disciplinas fundamentais para este processo de inovação e aprendizagem: domínio pessoal, modelos mentais, visões partilhadas, aprendizagem em grupo, pensamento sistêmico" (Fleury, 1997). Essas disciplinas não aparecem simplesmente nas empresas, elas devem ser trabalhadas e planejadas para que em longo prazo seja construida uma cultura sólida.

Esse pensamento fica mais claro quando se observa as idéias de Schein (1992) sobre os pressupostos básicos que dariam sustentação a uma cultura de aprendizagem, os quais podem ser sintetizados em termos de:

$\Rightarrow$ Relação da organização com o ambiente - a organização é dominante,

$\Rightarrow$ Natureza da atividade humana: proativa,

$\Rightarrow$ Natureza da realidade e da verdade: pragmática,

$\Rightarrow$ Natureza humana: boa e mutável.

$\Rightarrow$ Natureza das relações humanas: individualismo $\mathrm{X}$ grupismo e autoritarismo $\mathrm{X}$ participação,

$\Rightarrow$ Natureza do tempo: orientado para o futuro,

$\Rightarrow$ Comunicação: intensa,

$\Rightarrow$ Diversidade de subculturas,

$\Rightarrow$ Orientação para as tarefas e para as relações interpessoais, 
$\Rightarrow$ Pensamento sistêmico.

Um outro apoio à cultura de aprendizagem "está na própria estrutura da organização. A forma como a empresa se organiza, pode definir como será a relação entre as pessoas, criando aspectos favoráveis ao aprendizado e ao melhoramento contínuo. o qual. como já foi explanado. facilita e flexibiliza as mudanças.

\subsection{A Influência do Enfoque Estrutural na Mudança Cultural}

A mudança estrutural de uma organização é um dos enfoques que pode estar relacionando diretamente a mudança cultural. Algumas estruturas modernas estão claramente voltadas para aspectos culturais, o conceito de organizações que aprendem. ou seja, de empresas que possuem uma estrutura organizacional baseada na aprendizagem continua como vantagem competitiva, por exemplo, possuem a idéia clara de criar através da forma de organização uma cultura favorável à mudança, que aprenda continuamente.

A teoria sociotécnica é um dessas estruturas, nela os objetivos organizacionais são alcançados explorando a adaptabilidade e a criatividade das pessoas. dessa maneira valoriza-se o funcionário com capacidade para estar sempre aprendendo. Nessa forma de organização as pessoas são organizadas em grupos semi-autônomos, ou seja, os grupos possuem uma interdependência, mas os papéis das pessoas são definidos dentro do grupo. Eric Trist, um dos fundadores da abordagem sociotécnica, observa que, "vistos como sistemas abertos, os grupos semi-autônomos são sistemas de trabalho com um espaço para negociação e decisão que tendem a aumentar à medida que se desenvolve a capacidade do grupo para a solução de problemas e para a absorção das funções de manutenção e controle. Os grupos semi-autônomos são capazes de adquirir conhecimentos e evolução - são learning systems" (Fleury, 1997).

A abordagem japonesa é um exemplo ainda mais significativo, evoluída a partir da prática da produção nas indústrias japonesas, ela enfatiza um gradual e consistente processo de aprendizagem. "A organização e a utilização do conhecimento operário nas empresas japonesas diferem da proposta sociotécnica. Nesta. a questão da aprendizagem e do conhecimento justificase a partir do potencial de crescimento das pessoas e da colocação desse potencial a serviço das 
empresas. Nas empresas japonesas. o uso e o desenvolvimento de conhec̀imentos são fortemente objetivados e associados à estratégia competitiva da empresa através da organização das chamadas Atividades de Pequenos Grupos (Small Group Activities)" (Fleury, 1997).

O conceito de trabalho em grupo desenvolvido no modelo japonês tem raizes na própria cultura do país, onde a religião já enfatiza esse tipo de comportamento, por esse e outros motivos deve-se tomar cuidado ao analisar o modelo japonês, pois muitos estudiosos e consultores têm questionado sua qualificação como modelo propriamente dito, restringindo sua real possibilidade de transferência e utilização fora da sociedade japonesa. Independente disso é inegável que essa postura advinda da filosofia oriental Kaizen do contínuo melhoramento, tem aumentado a competitividade das empresas japonesas, minimizando os impactos durante os processos de adaptação e inovação.

Um novo modelo que vem se difundindo é o das chamadas organizações qualificantes. que se baseia em incentivar o aprendizado e o desenvolvimento das capacitações. As empresas que seguem esse modelo caracterizam-se por trabalharem em equipes ou células, com autonomia delegada às células e sua responsabilização pelos objetivos de desempenho. Além disso, a diminuição dos níveis hierárquicos e o desenvolvimento das chefias para atividades de motivação e gestão de recursos humanos, juntamente com a reaproximação das relações entre as funções da empresa são outras características desse tipo de organização.

Pode-se observar que o trabalho em grupo, onde se entende por grupo pessoas trabalhando em um espírito de equipe organizando-se com autonomia e buscando uma meta bem definida, é uma constante nos modelos de organizações que enfatizam o aprendizado. Em resumo o que temos é um paradigma sobre o qual as empresas dispostas a mudar são as empresas que aprendem e que para isso valorizam e se utilizam do conhecimento de seus colaboradores, observando as suas competências e valorizando enormemente o seu desenvolvimento.

Apesar das facilidades à mudança criadas pelas organizações estruturadas ao aprendizado, quando se analisa a necessidade de competitividade atual, deve-se necessariamente incorporar aspectos de inovação a mudança. As empresas não podem apenas querer evoluir e melhorar, a empresa deve se diferenciar, introduzindo de tempos em tempos rupturas através de inovações. Dessa forma ao se estruturar uma companhia para que esta esteja voltada a flexibilidade e assim suscetível à mudança, é importante que a estrutura aborde dois aspectos: 0 do aprendizado, conforme discutido anteriormente e o da inovação. 
A estrutura. inovativa é uma estrutura 'orgânica', onde a tarefa individual muda constantemente como resultado da interação com demais membros da organização, o sistema de controle é menos baseado no contrato de trabalho feito entre o indivíduo e a organização representada pelo seu chefe e mais baseado no consenso do que é bom para o grupo, à autoridade pode mudar dependendo de quem é mais capaz para realizar a tarefa, a comunicação lateral além de vertical e o conteúdo da comunicação na organização tende a ter mais informação e conselho ao invés de instruções e decisões.

As estruturas inovativas apresentam um baixo índice de formalização e utilizam formas avançadas de departamentalização. na tentativa de flexibilizar as ações dos gerentes, tomando-se mais adaptável ao ambiente em mudança. Entre essas novas formas. mais flexíveis e avançadas. temos conforme dito por Vasconcellos et all:

Departamentalização por centros de lucro - Utiliza critérios tradicionais com a diferença que divide a empresa em centros de lucro, onde as unidades possuem alto grau de autonomia agindo como se fossem empresas isoladas;

Departamentalização por projetos - Agrupa as pessoas utilizando como critério o projeto no qual estão envolvidas naquele determinado instante

Departamentalização matricial - É a utilização simultânea de dois ou mais tipos de departamentalização sobre o mesmo grupo de pessoas. Geralmente é a combinação entre os tipos Funcional e Por Projetos ou Por Produtos.

Departamentalização celular - É caracterizada pela quase total ausência de estrutura e alta flexibilidade, sendo a informalidade muito elevada.

Departamentalização por novos empreendimentos - Baseada no pré-suposto que atividades de inovação deveriam ser separadas de atividades de rotina, cria uma estrutura própria para os novos empreendimentos, só assimilando-o à área operacional quando a inovação for aceita.

O que se observa nos estudos atuais é que dentre as novas formas de departamentalização, as estruturas bidimensionais são as que mais flexibilizam as ações dos gerentes, distribuindo melhor a utilização dos recursos e criando um clima mais colaborativo. Também chamada de matricial, essa estrutura foi popular nos anos 70 e perdeu prestigio nos anos 80, quando muitas empresas tiveram dificuldade em implementá-las. Nos anos 90, entretanto, ela voltou fortalecida. As razões para esse ressurgimento incluem pressões para as 
empresas consolidarem custos e serem mais rápidas no mercado, criando uma necessidade de coordenação entre os países para as empresas com estratégias globais.

\subsection{Aspectos relevantes}

O que os conceitos de cultura organizacional trazem é a clara visão que a mudança. mesmo quando restrita a introdução de uma nova tecnologia em apenas um pequeno projeto. envolve os conceitos e pressupostos por traz das pessoas que constituem a organização e a forma como esta é estruturada. Dessa maneira, quando se pretende passar por um processo de mudança. deve-se antes entender a organização e então prepara-la para receber a mudança, pois quando a organização e os responsáveis pela mudança encontram-se preparados, estimular o restante da organização para mudança torna-se mais fácil. Para isso é importante notar e entender que a cultura, principalmente a cultura por traz de organizações motivadas ao aprendizado, não faz com que as barreiras à mudança desapareçam, é necessário que as pessoas estejam motivadas e comprometidas com a mudança.

Entender a cultura e os aspectos intrínsecos à mudança é sem dúvida importante para que ferramentas possam ser usadas de forma mais efetiva quando barreiras são encontradas. Mas assim como a aprendizagem contínua é um estado cultural fundamental para a competitividade, 0 ideal é que a própria cultura fosse uma cultura de mudança.

A cultura da mudança, por si mesma, facilita a introdução de novas idéias e torna o processo de mudança um hábito comum. "Este ambiente propício à mudança engloba fatores como gestão participativa, envolvimento de funcionários, sistemas de trabalho, comunicação, ambiente físico, clima organizacional, formas de trabalho, relacionamentos, enfim. envolve um conjunto de variáveis que se relacionam diretamente aos recursos humanos da empresa e influenciam a organização e execução do trabalho" (Bitencourt, 1996). Dessa forma, pode-se dizer que "uma empresa possui uma cultura da mudança quando seus funcionários são estimulados, permanentemente, a adotar novos comportamentos, mudar paradigmas, introduzir inovações e a correr riscos conscientes porque se sentem seguros de que, caso falhem ou fracassem. isto não será motivo para serem excluídos, humilhados ou rejeitados" (Marcondes, 1996, pág. 2). 
Mudar apenas por mudar sem um objetivo de melhoria e aperfeiçoamento, não faz sentido algum. É importante que a organização tenha a visão dos. objetivos da mudança e que a cultura da mudança recaia sobre a cultura da aprendizagem. Para isso "uma empresa que possui a cultura da mudança, aceita os erros honestos; estimula e mantém condições para elevar a autoestima dos seus funcionários; e pratica processo decisório que efetivamente garante participação. voz e veto a todos os envolvidos nas decisões especificas" (Marcondes, 1996, pág. 3). Dessa forma o medo de aprender é suprimido e as chances de acertar na mudança crescem. Resumindo para enfrentar as barreiras que aparecem durante um processo de mudança. deve-se entender a cultura por traz das atitudes das pessoas e utilizar as ferramentas de motivação e os agentes facilitadores para não apenas romper essas barreiras, mas transformar essa cultura em uma cultura da mudança que muda seguindo o aprenclizado contínuo.

\subsection{Considerações Finais}

Neste capitulo foram apresentadas noções sobre mudança e gerenciamento de pessoas da área de administração de empresas. focando-se as pessoas e suas relações com o sistema organizacional. Com base nesses conhecimentos. no próximo capítulo identifica-se quais KPAs do P-CMM podem ser usadas para minimizar barreiras em um programa de melhoria de processo de software. 


\subsection{Considerações iniciais}

Neste capitulo mostra-se quais KPAs do People Capability Maturity Model podem ser utilizadas para acelerar o programa de melhoria de processo e de que maneira elas afetam o programa. criando assim uma cultura de melhoria continua. Utiliza-se para isso as teorias de administração de empresas do capítulo anterior. Analisa-se também como as KPAs agrupam-se em aspectos organizacionais e como esses grupos influenciam de forma geral o processo de mudança. Em seguida mostra-se como as KPAs que agilizam a melhoria de processo de software podem ser implantadas por empresas de pequeno e médio porte.

\section{2 Áreas de atuação para quebra de barreiras}

O objetivo do People Capability Maturity Model é melhorar a qualidade do software através das pessoas que desenvolvem o software. As áreas chaves desse processo procuram melhorar a capacidade e a formação de quem desenvolve o software e a interação desses com e empresa e entre si. Aproveitando esse foco nas pessoas e na mudança de cultura que as KPAs do P-CMM possuem, procurou-se identificar quais dessas Áreas Chave de Processo podem atender os requisitos, encontrados nas teorias administrativas, que facilitam a melhoria de processo e viabilizam a mudança cultural.

O P-CMM possui um framework evolucionário interligando todas as KPAs e indicando como implanta-las que é estruturado para empresas de médio a grande porte. A visualização das KPAs do P-CMM como agentes de mudanças não o desvincula de sua estrutura, mas torna mais fácil identificar-se elementos que sejam aplicáveis a pequenas e médias empresas. A seguir cada KPA é descrita na visão de facilitador de mudança. 


\subsubsection{Ambiente de trabalho}

A manutenção do ambiente de trabalho fornecendo os recursos necessários para que cada individuo realize suas tarefas com eficiência fornece indiretamente um ambiente de segurança e bem estar. Um ambiente sem distrações, com uma estrutura física que preserve a higiene, 0 conforto e todas as leis e regulamentos aplicáveis, supre a necessidade de segurança das pessoas conforme nos mostra as teorias de Maslow (Hampton, 1992).

A importância dessa KPA pode ser mais bem entendida pensando-se na teoria motivação/higiene de Herzberg (Hampton, 1992), onde o Ambiente de Trabalho seria um dos fatores de higiene ou manutenção.

O próprio P-CMM considera essa KPA uma das bases para a motivação. mostrando que a avaliação e análise do desempenho são um fator motivacional. mas que para isso deve-se criar condições para esse desempenho. Seguindo-se as orientações do P.CMM para melhoria do ambiente de trabalho, criamos um dos primeiros fatores para motivação das pessoas à mudança.

\subsubsection{Comunicação}

A melhoria da qualidade e da distribuição da informação facilita a coordenação entre grupos e desenvolve canais de comunicação mais eficientes. Mas, essa democratização da informação e desburocratização dos canais de comunicação também torna toda e qualquer informação acessivel a todos com qualidade e rapidez.

O desenvolvimento da comunicação melhora o modo como as pessoas interagem, criando uma cultura de participação e facilitando a construção de times, conforme mostra o PCMM. Mas. além disso, a comunicação mais democrática torna o processo de mudança mais transparente a todos, pois se elimina o poder sobre a informação, acarretando inclusive mudanças institucionais e organizacionais. Portanto, ao se institucionalizar essa capacidade, conforme propõe o P-CMM, cria-se um dos mais importantes agentes facilitadores de mudança, a comunicação clara e transparente.

\subsubsection{Staffing}

O P-CMM mostra a importância de se ter uma força de trabalho adaptada às necessidades da organização, suprindo todos os requisitos necessários ao desenvolvimento do seu produto. 
Para isso propõe a melhoria no processo de recrutamento e seleção de candidatos e na orientação dos contratados durante a transição para a nova função.

A melhoria nesse processo permite montar uma força de trabalho mais proativa e mais favorável a mudanças e inovações. basta para isso acrescentar aos perfis necessários ao desenvolvimento de software, a caracteristica de ser inovador e como tal simpatizante de mudanças continuas. Portanto. para visualizar o P-CMM como uma ferramenta que facilita mudanças. acrescentasse as competências essenciais da organização à melhoria contínua e a aceitação de mudanças.

\subsubsection{Administração de desempenho}

Medir, discutir e reconhecer o desempenho de todos que colaboram com a organização é outra área que segundo o P-CMM leva ao objetivo da motivação.

Portanto se o objetivo é motivar a mudança, pode-se medir, discutir e reconhecer o desempenho em mudar. A avaliação çontínua do esforço em mudar. significa uma administração continua do processo de mudança. Esse acompanhamento do desempenho, mostra para toda força de trabalho a importância que o projeto de melhoria de processo de software tem para a organização. Isso porque o desempenho na mudança do processo é avaliado e comentado.

\subsubsection{Treinamento}

O desenvolvimento das capacidades, habilidades e conhecimentos dos funcionários necessários à organização, garantem o bom desenvolvimento de software e também motiva a força de trabalho que percebe a atualização e melhoria do conhecimento como benefício.

Mas o mesmo princípio de melhoria do treinamento pode ser usado para criar um perfil mais genérico para cada membro da força de trabalho, acrescentando-se treinamentos de interesse pessoal. Isso torna a equipe mais propensa à inovação e criatividade, conforme indicado nas estruturas orgânicas. 


\subsubsection{Compensạ̧̧āo}

Na área de Compensação cria-se estratégias de premiação do desempenho e do esforço em melhorar o processo. Cria-se também um plano de manutenção e desenvolvimento dessas estratégias. Isso é uma seqüuencia da KPA administração de desempenho.

Criar estratégias de remuneração não apenas eqüitativa às qualificações, mas que premie o esforço em mudar e melhorar o processo de desenvolvimento e leve em conta o trabalho em grupo.

Mudar um processo com intuito de melhorá-lo é antes de qualquer coisa um projeto e um difícil projeto. Por isso é necessário que toda a força de trabalho se envolva e trabalhe em equipe em pró da mudança. Logo é necessário que se crie os mecanismos necessários para se valorizar essas atitudes.

\subsubsection{Análise de conhecimento e habilidades}

A análise dos conhecimentos e habilidades é identificar as competências necessárias ao negócio, avaliando continuamente as já existentes e identificando as "core competence" a serem desenvolvidas.

No entanto, a organização que quer desenvolver software cada vez melhor deve melhorar seus processos continuamente e para isso deve ter a inovação e a mudança contínua como uma "core competence". Logo se devem analisar os conhecimentos e habilidades necessárias a criatividade e inovação para que exista cultura favorável à mudança.

Portanto, deve-se usar o estabelecimento dessa KPA para no momento de implantar-se um projeto de melhoria de processo de software, identificar e desenvolver na força de trabalho o perfil necessário a essa peculiar tarefa.

\subsubsection{Planejamento da força de trabalho}

A identificação dos conhecimentos e habilidades necessárias para o sucesso do projeto de melhoria de processo de software é uma tarefa complexa, mas não é suficiente.

Visualizar detalhadamente as necessidades de inovação e cultura de mudança deve vir acompanhado de um planejamento da utilização, desenvolvimento e treinamento desses 
conhecimentos e habilidades. Dessa maneira, baseado nas necessidades inerentes à mudança planeja-se a alocação e o desenvolvimento da força de trabalho nesse processo.

\subsubsection{Desenvolvimento de Competências}

Seguindo a própria estrutura das KPAs do P-CMM, mas sob a nova visão, o desenvolvimento de competências deve criar um programa de treinamento para desenvolver a criatividade. a inovação e a cultura favorável à mudança, de acordo com as necessidades de cada um.

Para isso, primeiro identifica-se como sendo uma "core competence" a necessidade da cultura favorável à mudança, baseada na criatividade e inovação, conforme descrito na KPA Análises de Conhecimentos e Habilidades. Em seguida planeja-se o desenvolvimento dessas competências conforme indica a KPA Planejamento da Força de Trabalho. Por fim esse planejamento é desenvolvido através de um programa de treinamento.

Identificar, desenvolver e valorizar as competências dos que colabóram com a mudança é um dos requisitos para as estruturas inovativas.

\subsubsection{Desenvolvimento de Carreira}

Planejar a carreira de.cada colaborador. mostrando as carreiras existentes, seus objetivos e habilidades exigidas, oferecendo orientação e treinamento nessas habilidades. Isso motiva o desenvolvimento de habilidades adicionais, oferecendo possibilidade diferente de carreira, valorizando com isso as competências pessoais e favorecendo o clima de inovação.

No momento em que cada membro da força de trabalho tem o desenvolvimento profissional alinhado com seus horizontes de conhecimento ampliados e suas competências pessoais, o esforço em inovar e melhorar passa a ser natural.

\subsubsection{Práticas Baseadas em Competência}

Gerenciar as atividades desenvolvidas, de modo que as pessoas e grupos envolvidos tenham exatamente o perfil de competências e habilidades mais adequado para a tarefa. Essa 
atitude garante que todos na força de trabalho estarão fazendo aquilo que sabem e gostam, sendo assim produtivos e conseqüentemente sentindo-se motivados.

Ao mudar-se o processo de desenvolvimento de software pensando-se nos papéis que cada membro da força de trabalho irá assumir, com base em suas competências pessoais. identifica-se um motivo comum para que todos queiram mudar. Logo. se pensarmos em um processo de mudança alinhado com as práticas baseadas em competências, criamos o estimulo necessário para criar a necessidade de mudança.

No entanto é importante notar que, sem a análise dos conhecimentos e habilidades da força de trabalho e o seu planejamento, alinhado ao desenvolvimento das competencias pessoais e o desenvolvimento de carreira é dificil localizar e organizar as práticas do processo de desenvolvimento de acordo com as competências de cada um.

\subsubsection{Cultura de Participação}

Repassando-se decisões para os níveis hierárquicos inferiores. cria-se autonomia para que os grupos negociem e participem de todo o processo decisório. Todos do grupo passam a colaborar no processo decisório e informações sobre os objetivos e porquês das decisões são claramente passadas a todos.

Essa cultura de participação criada leva ao comprometimento de todos com o processo de mudança, pois as decisões são feitas com a colaboração de todos os envolvidos. Ao participar das decisões, a força de trabalho torna-se comprometida com o processo de mudança $e$ conseqüentemente com o seu sucesso.

\subsubsection{Mentoring}

Mentoring é o uso da experiência da força de trabalho para liderar os novos membros, guiando-os durante a carreira e nas atividades. Esse processo é um incentivo ao desenvolvimento de líderes. E os líderes são fontes de apoio durante os processos de mudança.

Um programa de desenvolvimento e identificação de líderes dentro da organização é fundamental, pois o papel do líder como agente de mudança é um fator de alta relevância, durante a implantação de qualquer modificação nos processos atuais da organização. É o líder que mantém as pessoas centradas no objetivo da mudança e é nele que as pessoas se apóiam no 
momento de transpor qualquer obstáculo, principalmente durante uma situação delicada e incerta como é o processo de mudança.

\subsubsection{Construção de Times}

A formação de equipes com a integração de diversos conhecimentos e habilidades é um agente facilitador típico de estruturas voltadas a aprendizagem. onde o incentivo ao trabalho em grupo e a construção de equipes é incentivado.

A estruturação da organização para permitir a formação de grupos de trabalho com conhecimentos complementares necessários ao desenvolvimento do projeto permite um trabalho em equipe que melhora o desempenho do projeto e agiliza as mudanças necessárias.

\subsubsection{Práticas Baseadas em Times}

Estruturar as tarefas e funções da organização para serem executadas por equipes. Essa atitude apesar de ter pouca influência direta no processo de mudança, fortalece o conceito de trabalho em grupo, o chamado "teamwork".

Esse conceito é importante. pois as organizações orgânicas são estruturadas para desenvolver atividades em equipes. Isso porque o trabalho em equipe fortalece a criatividade e a mudança e também torna mais simples a administração do pessoal durante o processo de mudança.

A administração de pessoal é simplificada, pois se pode localizar mais facilmente os focos de resistência e seus motivos, isolando-os nas próprias equipes e tratando cada caso particularmente. Em resumo, trata-se do fortalecimento, ou complemento do conceito de construção de times.

\subsubsection{Administração de Competências Organizacionais}

Comparar, medir e guiar o desenvolvimento das "core competence" baseado no mercado. Dessa forma, realinha-se o desenvolvimento de competências baseado no próprio mercado concorrente. 
Apesar de pouco relacionado ao processo de mudança, essa KPA é um fator motivacional quando se pensa em evitar o overhead de pessoal. Dessa forma administrar as competências organizacionais é importante, pois o foco sempre é mudar as pessoas e não de pessoas.

É importante para as pessoas que participam de um processo de mudança acreditar que isso as tornarão mais competitivas e valorizadas no mercado. Pois em um setor onde os profissionais são tão concorridos, como no caso da informática, a motivação não vem apenas de promoções e salários.

\subsubsection{Alinhamento de Desempenho Organizacional}

Avaliação e guia do desempenho de grupos e equipes em relação às "core competence" da organização. Avaliação e reconhecimento do esforço em trabalhar em grupo. Reconhecimento do desempenho do grupo e não de alguns indivíduos.

Uma visão mais evoluida da avaliação da força de trabalho durante o processo de mudança. Avalia-se agora a contribuição de cada grupo para a "core competence " de evolução contínua dos processos. Também é avaliada a contribuição de cada participante do time para o sucesso da equipe.

Esse tipo de avaliação, apesar de complexa e difícil de implementar é importante para as fases mais adiantadas do processo de melhoria. Conforme proposto pelo próprio PCMM, essa avaliação é um fator de motivação ao trabalho em equipe e a resultados alinhados as necessidades da organização.

\subsubsection{Desenvolvimento de Competência Pessoal}

Desenvolvimento profissional individual. Aproximação do uso das competências individuais nos negócios da empresa. Aproveitamento dos conhecimentos individuais, mesmo que desvinculado ao negócio da empresa, como fonte de inovação.

Não se pode dizer que o Desenvolvimento de Competência Pessoal atue sob as barreiras que atrapalham o processo de melhoria de software. Mas incentivar a inovação, cultivando uma cultura que propicie o seu desenvolvimento é uma maneira de criar uma cultura mais favorável à mudança. 


\subsubsection{Coaching}

A formação de especialistas comprometidos com a melhoria de desempenho dos grupos e indivíduos é na verdade um refinado programa de liderança onde uma pessoa é comprometida a apoiar a equipe a atingir um determinado resultado.

Esse resultado pode ser o de adquirir competências e/ou produzir uma mudança específica. Não significa, entretanto, um compromisso apenas com os resultados, mas sim com 0 grupo como um todo, seu desenvolvimento e sua realização.

Utilizar a experiência existente na organização é, portanto mais um uso do papel do líder como agente facilitador de mudança.

\subsubsection{Inovaçāo Continua da Força de Trabalho}

Melhorar o processo de desenvolvimento de software é mudar continuamente focando a melhoria. Mas para isso temos que melhorar a força de trabalho que desenvolve o software.

Logo. para evitar problemas no processo de melhoria de software, não podemos esquecer da força de trabalho envolvida. E uma forma de fazer isso é identificando-se e implantando-se, constantemente, melhorias e novas tecnologias nas práticas da força de trabalho, ou seja, inovando continuamente a força de trabalho.

\subsection{Objetivos gerais no processo de mudança}

Ao longo dos niveis do P-CMM, as KPAs complementam-se tentando atingir um objetivo específico de melhoria. Dentro da visão de facilitador de mudança, esse agrupamento passa a ter o objetivo de mudar um aspecto organizacional especifico, que influencia a cultura, criando um ambiente favorável à mudança.

As diversas faces que compõe a organização permeiam todas as partes da empresa, inclusive a sua cultura. Dessa maneira, ao agrupar-se as KPAs por aspectos organizacionais, identifica-se a linha comum pela qual essas KPAs influenciam na cultura. 
Em resumo, pode-se agrupar as KPAs por aspectos organizacionais que facilitam a aceitação da mudança e a colaboração com o processo de mudança e, portanto, com os processos de melhoria. Esse resumo é descrito na tabela a seguir:

\begin{tabular}{|c|c|c|}
\hline KPA & Aspecto Organizacional & Influência na Mudança \\
\hline $\begin{array}{c}\text { Coaching } \\
\text { Desenvolvimento de Competência } \\
\text { Pessoal } \\
\text { Mentoring } \\
\text { Desenvolvimento de Competência } \\
\text { Conhecimento e Análise de } \\
\text { Habilidades } \\
\text { Treinamento } \\
\text { Comunicação } \\
\end{array}$ & Aspecto institucional & $\begin{array}{l}\text { Identificação e desenvolvimento das } \\
\text { capacidades, habilidades e conhecimentos } \\
\text { dos individuos e da própria organização. } \\
\text { Desenvolvimento contínuo do } \\
\text { conhecimento e das habilidades } \\
\text { individuais e da organização. Ou seja, } \\
\text { desenvolvimento da cultura de } \\
\text { "Aprendizagem contínua" }\end{array}$ \\
\hline $\begin{array}{l}\text { Construção de Times } \\
\text { Cultura de Participação } \\
\text { Comunicação }\end{array}$ & Aspecto Organizacional & $\begin{array}{c}\text { Melhoria no modo como as pessoas são } \\
\text { organizadas e interagem. } \\
\text { O trabalho em equipes, a comunicação } \\
\text { mais democrática e o gerenciamento } \\
\text { participativo definem as organizações } \\
\text { orgânicas. }\end{array}$ \\
\hline $\begin{array}{c}\text { Alinhamento de Desempenho } \\
\text { Organizacional } \\
\text { Práticas baseadas em times } \\
\text { Práticas Baseadas em Competência } \\
\text { Desenvolvimento de Carreira } \\
\text { Compensação } \\
\text { Administração de Desempenho } \\
\text { Ambiente de Trabalho }\end{array}$ & Aspecto Comportamental & $\begin{array}{l}\text { Avaliação e análise de desempenho } \\
\text { criando condições para a melhoria de } \\
\text { desempenho. Reconhecimento e } \\
\text { premiação pela melhoria. }\end{array}$ \\
\hline $\begin{array}{l}\text { Administração de Competências } \\
\text { Organizacionais } \\
\text { Planejamento da Força de Trabalho } \\
\text { Staffing }\end{array}$ & $\begin{array}{l}\text { Aspecto Organizacional \& } \\
\text { Aspecto Comportamental }\end{array}$ & $\begin{array}{l}\text { Recrutamento e seleção da força de } \\
\text { trabalho baseados nas competências da } \\
\text { organização. Além de orientação para o } \\
\text { desenvolvimento individual nessas } \\
\text { competências }\end{array}$ \\
\hline $\begin{array}{l}\text { Inovação Contínua da Força de } \\
\text { Trabalho }\end{array}$ & -- & Melhoramento e mudança continua. \\
\hline
\end{tabular}

Tabela 4-1: Resumo KPAs X Aspectos organizacionais 


\subsection{KPAs prioritárias para facilitar a melhoria de processo}

A interpretação do P.CMM, através das teorias administrativas, identificou em todas as KPAs, elementos que facilitam o processo de mudança. No entanto, conforme já explanado. implantar todo o P-CMM é inviável para a maioria das empresas. Por esse motivo foram identificadas as KPAs que são claramente prioritárias no trabalho de minimizar barreiras a melhoria de processo.

Para determinar as KPAs prioritárias baseou-se no conceito de agente facilitador por ser um dos mecanismos que facilitam a mudança e motivam a colaboração com a melhoria do processo conforme detalhado no item 3.6 da página 33. Lembrando que como agentes facilitadores tem-se a Comunicação, o treinamento, a recompensa, o benchmarking, o papel exercido pelo líder, o perfil do trabalhador, a redução de níveis hierárquicos, os formadores de opinião. a informalidade e transparência nas relações internas da empresa entre outros.

Entre as KPAs que são claramente agentes facilitadores de mudança temos Coaching e Mentoring (atuando no papel exercido pelo líder), Treinamento, Construção de Times e Práticas baseadas em times (atuando no trabalho em equipe), Cultura de Participação (atuando na administração participativa), Comunicação, Compensação (atuando na recompensa), Staffing (atuando no perfil do trabalhador). Como os principais agentes facilitadores e também os mais comentados na literatura são os que envolvem comunicação e o papel exercido pelo líder, temse, Coaching, Mentoring e Comunicação como KPAs prioritárias para facilitar a melhoria de processo.

O problema é que o programa de Coaching é algo fora da realidade da maioria das empresas de software no Brasil, que não possuem grandes estruturas de equipes. Conseqüentemente também não possuem pessoas comprometidas com uma única equipe. As empresas de software na verdade funcionam como uma grande equipe e o papel de Coaching de certa forma, acaba sendo exercido pelo dono da empresa ou pelo seu principal executivo. Assim escolhe-se as KPAs Comunicação e Mentoring, como sendo as áreas as quais deve ser dado atenção durante a melhoria de processo. Comunicação e Mentoring além de prioritárias para agilizar a melhoria de processo são duas KPAs, que no entender deste trabalho, podem ser implantadas pelas empresas de software.

Pensando-se em exemplificar o uso dessa nova visão dada ao P-CMM e também preparar uma empresa para mudança de processo, criou-se um procedimento de implantação dessas 
KP.As. Para tanto será feito uma complementação da revisão bibliográfica detalhando as KPAs Comunicação e Mentoring.

O detalhamento dessas KPAs segue a estrutura do P-CMM, ou seja, as atividades da KPA são agrupadas em cinco categorias: compromissos preliminares, habilidades necessárias. atividades para realizar, medidas e analises e verificação da implementação.

\subsection{Comunicação}

Quando uma empresa resolve iniciar um programa de melhoria do processo de software. algumas decisões são tomadas. Decisões como qual modelo a ser usado, quem serão os responsáveis, os motivos da melhoria, os objetivos a serem alcançados, entre outras devem ser informadas a todos. Da mesma forma todas as decisões e resultados durante o processo deve ser distribuido através de canais de comunicação eficientes.

\subsubsection{Compromissos Preliminares}

Compromisso 1: Os administradores estabelecem e comunicam um conjunto de valores relativos ao desenvolvimento e administração da força de trabalho.

Exemplos de assuntos cobertos nos valores de uma empresa pensando-se em um processo de mudança podem ser:

- Os compromissos implícitos e explícitos entre a organização e sua força de trabalho;

- Os compromissos para o desenvolvimento do talento e do desempenho;

- O modo de tratamento dos indivíduos;

- Direitos da força de trabalho, principalmente durante a mudança;

- Comunicação aberta sem medo de represália;

- Énfase em teamwork;

- Valores e atributos culturais desejados e os esperados com a mudança;

- Compromisso para melhoria contínua das atividades relacionadas às pessoas;

Para estabelecer e comunicar esses conjunto de valores os administradores devem: 
1. Documentar um conjunto de valores para guiar o comportamento das pessoas na organização durante a mudança.

2. Endossar publicamente os valores que foram documentados.

3. Assegurar que esses valores sejam comunicados a todos os membros da força de trabalho.

Exemplos de métodos para comunicar os valores da organização incluem:

- Exibição pública da declaração de valores,

- Discussão aberta de assuntos relacionados aos valores, usando os canais de comunicações apropriados.

- Usar e aplicar explicitamente os valores quando executar atividades relacionadas às pessoas.

- Referenciar e guiar através dos valores explicando as decisões.

4. Derivar políticas e procedimentos a partir dos valores para as atividades relacionadas às pessoas.

5. Estabelecer mecanismos para assegurar que todas as atividades relacionadas às pessoas obedeçam aos valores da organização.

6. Obrigar uma ação corretiva quando alguma atividade relacionada às pessoas não seguir os valores da organização.

7. Assegurar que todas as decisões e ações executivas possuem apoio consistente nos valores da organização.

Compromisso 2: A organização segue uma política documentada para administrar suas atividades relacionadas à comunicação.

Essa política, tipicamente especifica:

1. A relação entre as atividades de comunicação e os objetivos empresariais e valores documentados da organização.

2. A importância de manter um ambiente aberto que apóie o fluxo de comunicação em todas as direções.

3. A exigência de comunicação periódica das informações organizacionais para todos os indivíduos e grupos. 
4. A exigência de desenvolvimento de habilidades de comunicação em todos os indivíduos e grupos.

5. As oportunidades existentes para que as críticas e reclamações sejam levantadas e solucionadas.

Compromisso 3: Um cargo organizacional é indicado para ter a responsabilidade de ajudar e aconselhar as pessoas nas atividades relacionadas à comunicação.

Exemplos de individuos ou grupos que poderiam ajudar e poderiam aconselhar nas atividades relacionadas à comunicação incluem:

- Grupo de recursos humanos,

- Grupo de treinamento.

- Grupo de literatura técnica,

- Grupo de relações públicas ou outro grupo de comunicações

\subsubsection{Habilidades Necessárias}

Habilidade 1: Dentro de cada unidade, um individuo é nomeado como responsável por assegurar que as atividades relacionadas à comunicação sejam executadas.

Habilidade 2: Recursos adequados são fornecidos para implementar as atividades relacionadas à comunicação.

Para que essas duas habilidades existam os administradores devem:

1. Escolher os individuos experientes disponiveis, que tenham perícia em comunicação para as atividades relacionadas à comunicação.

2. Disponibilizar recurso financeiro adequado para as atividades relacionadas à comunicação.

3. Fornecer o apoio necessário para implementar melhorias na comunicação.

Habilidade 3: Os indivíduos responsáveis pela melhoria das comunicações são treinados em métodos pertinentes às suas responsabilidades.

Exemplos de treinamentos que podem facilitar a comunicação incluem:

- Treinamento nas habilidades de comunicação oral e escrita,

- Desenvolvimento de habilidades de comunicação em outros indivíduos,

- Desenvolvimento de habilidades de comunicação interpessoal, 
- Arbitragem/resolução de disputas.

- Facilitação de reuniões,

- Procedimentos de reclamações,

- Planejamento e execução de estratégias de comunicação organizacional,

- Como usar diferentes mídias de comunicação efetivamente.

\subsubsection{Atividades para executar}

Atividade 1: As políticas e as práticas da organização que são relacionadas às pessoas são comunicadas à força de trabalho.

1. Os indivíduos e unidades são informados das politicas e práticas que os afetam.

Exemplos de políticas e práticas relacionadas às pessoas devem ser comunicadas:

- Políticas de contratação,

- Treinamento compativel às necessidades de cada posição,

- Estratégias de compensação,

- Políticas de desenvolvimento de carreira,

- Práticas de retreinamento,

- Procedimentos para reclamações.

- Práticas de administração de desempenho.

2. Sempre que acontecem mudanças nas políticas e práticas relacionadas às pessoas, essas mudanças são comunicadas à força de trabalho.

3. A organização determina periodicamente se a força de trabalho está atenta as suas políticas e práticas relacionadas às pessoas.

4. Quando enganos nas políticas e práticas relacionadas às pessoas acontecem, uma ação corretiva é tomada.

Atividade 2: Administração comunica periodicamente os eventos da organização e as condições para a força de trabalho.

Exemplos de mecanismos de comunicação incluem:

- Reuniões organizacionais,

- Reuniões de pessoal,

- Reuniões individuais,

- Anúncios através de correio eletrônico, 
- Publicações internas,

- Folhetos informativos,

- Memorandos.

Atividade 3: As habilidades de comunicação necessárias para executar as tarefas são desenvolvidas.

1. Os supervisores avaliam se os indivíduos têm as habilidades de comunicação oral ou escrita exigida para executar as suas tarefas.

Exemplos de problemas de comunicação oral e escrita incluem:

* Alfabetização inadequada em um ou mais dos idiomas usados na organização:

- Falta de conhecimento sobre o jargão ou termos usados em um negócio ou domínio técnico específico;

- Protocolos de comunicação impróprios para a situação;

- Deficiência nas habilidades de oração ou redação:

- Falta de habilidade no uso de mídias de comunicação, como e-mail, processadores de texto, telefones, e assistentes digitais pessoais.

2. Quando falta aos indivíduos as habilidades de comunicação oral ou escrita necessárias para executar uma tarefa, uma ação corretiva é tomada.

Exemplos de ação corretiva incluem:

- Treinamento nas habilidades de comunicação oral ou escrita,

- Treinamento no uso de mídias de comunicação,

- Treinamento pessoal.

- Relocação de tarefas.

3. Treinamento nas habilidades de comunicação oral e escrita é instituído nas situações necessárias para o sucesso no desempenho das unidades e/ou dos indivíduos.

Atividade 4: As habilidades de comunicação interpessoais necessárias para estabelecer e manter efetivas relações de trabalho são desenvolvidas.

Exemplos de habilidades de comunicação interpessoal que apóiam as relações de trabalho incluem:

- Comunicação e dinâmica interpessoal,

- Comunicação e dinâmica de grupo,

- Protocolos de interação para situações específicas,

- Habilidades de resolução de problemas, 
- Habilidades de negociação,

- Sensibilidade multicultural e outras habilidades diversificadas relacionadas.

Atividade 5: Problemas ou conflitos interpessoais que degradam a qualidade ou efetividade das relações de trabalho são adequadamente manipulados.

Exemplos de maneiras apropriadas para manipular problemas interpessoais incluem:

- Melhorar as habilidades de comunicação interpessoais;

- Criar programas de Coaching para um ou mais indivíduos;

- Melhorar a dinâmica de grupo:

- Uso de um ombudsman, árbitro, ou facilitador;

- Relocação de um ou mais indivíduos:

- Ações de administração de desempenho;

- Ação disciplinar.

Atividade 6: As opiniões dos indivíduos sobre suas condições de trabalho são buscadas em eventos periódicos.

1. Opiniões são colecionadas em eventos periódicos.

Exemplos de mecanismos para colher opiniões individuais incluem:

- Análise de opinião em questionários de clima organizacional;

- Entrevistas com uma amostra da força de trabalho;

- Entrevistas com a administração. inclusive reuniões que permitam aos indivíduos pular níveis administrativos;

- Reuniões de grupo sobre o assunto:

- Revisões de postmortem;

- Caixa de sugestões ou outros meios privados;

- Meios eletrônicos.

2. As sugestões são analisadas e os resultados são preparados de acordo com o assunto estudado.

3. Feedback dos resultados dessas análises, decisões tomadas baseadas nestas análises, e ações resultantes dessas análises são comunicadas à força de trabalho.

4. Para assegurar confidêncialidade, os resultados são apresentados de modo que indivíduos ou grupos não possam ser identificados como a fonte de informação a menos que eles dêem a sua permissão. 
Atividade 7: Indivíduos ou grupos podem levantar queixas de acordo com um procedimento documentado.

1. O procedimento tipicamente especifica:

- Como uma reclamação ou assunto pode ser levantado;

- Requisitos para localizar e solucionar uma reclamação ou assunto;

- Como as respostas a uma queixa ou assunto devem ser fornecidas;

- Como administrar e registrar uma reunião, se necessário, discutir possiveis resoluções;

- Sequência de atividades após as reuniões de resolução de problemas:

- Como enviar uma queixa diretamente a alta administração se ela não puder ser solucionada em um nível inferior.

2. Indivíduos ou grupos podem levantar uma reclamação ou podem enviar a qualquer nível administrativo sem medo de represália.

Exemplos de mecanismos para levantar uma queixa ou assunto incluem:

- Escrever as reclamações ou assuntos e submeter a um individuo apropriado para disposição,

- Reuniões com o indivíduo apropriado ou gerente,

- Reuniões com alguém reconhecidamente neutro ou um ombudsman,

* Procedimentos formais de reclamação documentados.

3. Para resolução de uma reclamação ou assunto pode-se recorrer a niveis mais altos da administração.

Atividade 8: A administração caminha para atividades de encerramento relacionadas à resolução de uma queixa.

1. São distribuidas responsabilidades para localizar o estado das reclamações e dos assuntos pendentes.

2. A administração executiva periodicamente revisa o estado de todas as reclamações e assuntos abertos.

3. Quando não foi feito um progresso apropriado para solucionar uma queixa ou assunto, uma ação corretiva é tomada.

Atividade 9: Reuniões são conduzidas de modo a tornar mais eficiente o tempo usado dos participantes. 
1. São desenvolvidas diretrizes para se encontrar a máxima eficiência baseado na cultura e valores da organização, nos processos empresariais. e no propósito da reunião.

Exemplos de tópicos que devem ser listados como um guia de reuniões inclui:

* Propósito da reunião.

- Planejamento da reunião,

- Agenda da reunião e administração do tempo.

- Responsabilidades e papéis dos participantes,

- Quantidade de participantes e requisitos.

- Procedimentos da reunião.

- Localização e configuração da sala.

- Mecanismos de participação.

- Práticas para localizar itens de ação ou assuntos.

2. Reuniões são convocadas apenas se oferecem um adequado benefício durante o tempo consumido; caso contrário, um modo mais eficiente para realizar a meta é procurado.

3. Para uma possível extensão, são planejados o propósito, objetivos, e procedimentos da reunião, e um programa de trabalho é distribuido com antecedência.

4. Reuniões são conduzidas para manter o foco em realizar o seu propósito original.

5. Reuniões são conduzidas para encorajar a participação de todos que podem fazer alguma contribuição.

6. Ações para as reuniões seguintes são tomadas e caminha-se para as conclusões.

\subsubsection{Medidas e análises}

Medida 1 São feitas medidas que determinam o estado das atividades de comunicação.

Exemplos de medidas de atividades de comunicação incluem:

- Uso de mídia de comunicação,

- Número das pessoas treinadas nas habilidades de comunicação,

- Resultado das pesquisas de opinião.

- Número de conflitos interpessoais tratados através de mecanismos formais,

- Número de queixas ou assuntos levantados,

- Número de reuniões de reclamação ou assunto que foram requisitadas. 
- Tempo e esforço gastos para solucionar queixas e assuntos,

- Tempo gasto em reuniões,

- Taxa de itens de ação que são fechados em reuniões.

\subsubsection{Verificação da Implementação}

Verificação $1 \mathrm{Um}$ responsável verifica quais atividades de comunicação estão sendo conduzidas de acordo com as políticas documentadas da organização.

Estas revisões verificam se:

1. As atividades de comunicação obedecem aos valores estabelecidos, políticas, e procedimentos documentados da organização.

2. As atividades de comunicação são executadas de acordo com os planos da unidade e métodos selecionados.

3. Os itens em não conformidade são adequadamente manipulados.

Verificação 2 A administração executiva periodicamente revisa as atividades de comunicação da organização para determinar se elas obedecem às políticas documentadas da organização.

Estas revisões verificam:

1. A adaptação das atividades de comunicação com os valores estabelecidos, políticas, e procedimentos da organização.

2. O estado de resolução para assuntos de descumprimento.

3. O progresso no desempenho de qualquer atividade de comunicação planejada.

4. A taxa na qual os problemas sérios de comunicação estão sendo reduzidos.

5. As tendências relacionadas a assuntos de comunicação.

6. O número de queixas e assuntos levantados e a taxa de solução.

7. A adaptação das resoluções das queixas com o procedimento documentado da organização.

8. As tendências relacionadas às queixas e assuntos levantados. 


\subsection{Mentoring}

O propósito de Mentoring é usar a experiência da força de trabalho da organização para fornecer apoio pessoal e uma direção a outros indivíduos e grupos. Esse direcionamento pode envolver desenvolvimento de conhecimentos e habilidades. melhoria de desempenho. manipulação de situações difíceis, e tomada de decisões de carreira.

$\mathrm{O}$ uso do Mentoring por uma pequena empresa durante um projeto de melhoria de processo. compromete as pessoas mais experientes da força de trabalho com o projeto. Além disso, facilita o envolvimento dos mais novos e minimiza as necessidades de treinamento.

Criando um programa de Mentoring. a empresa esta desenvolvendo líderes que servirão de alicerce para o processo de mudança e também de guia para toda a força de trabalho. Além disso, as pessoas selecionadas para o Mentoring em geral são os formadores de opinião que ao participarem do programa tornam-se comprometidos com a mudança.

Para uma pequena empresa que não tem. na maioria das vezes, condições de disputar profissionais no mercado através de benefícios salariais, o programa de Mentoring torna-se também uma alternativa mais econômica de evitar a mudança de pessoas durante a melhoria de processo.

\subsubsection{Compromissos Preliminares}

Compromisso 1 A organização segue uma política documentada para as atividades de Mentoring.

Essa política tipicamente especifica que:

1. Atividades de Mentoring servem aos objetivos empresariais e aos valores declarados da organização.

2. Atividades de Mentoring são encorajadas, mas não impostas aos individuos.

3. Atividades de Mentoring serão incluídas na estratégia da organização e no planejamento da força de trabalho.

4. Atividades de Mentoring são instituidas onde for apropriado para fornecer apoio aos individuos e grupos. 
5. Procedimentos documentados são desenvolvidos e usados para guiar as atividades de Mentoring. Esses procedimentos tipicamente especificam:

- Requisitos para a seleção, treinamento, e as tarefas dos mentores;

- Condições sob as quais relações de Mentoring podem ser estabelecidas. alteradas, ou encerradas;

- Requisitos para avaliação periódica do programa para garantir sua efetividade e identificar melhorias.

Compromisso 2 Um cargo organizacional é designado para coordenar as atividades de Mentoring pela organização.

\subsubsection{Habilidades Necessárias}

Habilidade 1 O cargo organizacional designado para coordenar as atividades de Mentoring deve ter a disposição o número de pessoas necessário, com as habilidades necessárias.

Habilidade 2 Recursos humanos e financeiros adequados são fornecidos para as atividades de Mentoring.

Para garantir essas habilidades, os administradores devem:

1. Avaliar dentre os indivíduos experientes os que podem atuar como mentores.

2. Disponibilizar tempo para os mentores dos indivíduos ou grupos se ocuparem das atividades de Mentoring.

3. Fornecer os recursos necessários para apoiar as atividades de Mentoring.

Exemplos de recursos necessários no apoio ao programa de Mentoring incluem:

- Treinamento para mentores;

- Orientação para que individuos ou grupos tornem-se mentores;

- Disponibilização de um conselheiro para mentores, individuos, ou grupos;

- Apoio na avaliação do programa de Mentoring.

Habilidade 3 Os individuos selecionados para atuar como mentores são treinados nos objetivos, técnicas, e habilidades pertinentes ao Mentoring.

Exemplos de habilidades de Mentoring nas quais os mentores são treinados incluem:

- Como realizar os objetivos do programa de Mentoring,

- Como conduzir um relacionamento de Mentoring, 
- Fornecendo orientação e conselhos,

- Resolução de problemas,

- Métodos de melhoria de desempenho,

- Princípios de conhecimento e desenvolvimento de habilidade,

- Oportunidades de carreira e métodos de desenvolvimento,

- Grupos de aconselhamento,

- Construção de times.

- Métodos para integração com a cultura organizacional.

- Papéis a serem cumpridos,

- Como avaliar o sucesso do Mentoring.

Habilidade 4 Indivíduos ou grupos que receberão o Mentoring ganham orientação sobre o programa de Mentoring.

Exemplos de assuntos para orientação sobre o programa de Mentoring incluem:

- Objetivos do programa de Mentoring,

- Atributos de uma efetiva relação de Mentoring,

- Habilidades na resolução de problemas,

- Expectativas para as relações de Mentoring,

- Papéis a serem cumpridos no Mentoring,

- Como manipular problemas ou ineficiências na relação de Mentoring.

\subsubsection{Atividades para executar}

Atividade 1 Os objetivos e a estrutura do programa de Mentoring são definidos.

1. A administração identifica quais posições, indivíduos, ou grupos dentro da organização podem ser envolvidos em um programa de Mentoring.

2. A organização estabelece um ou mais conjuntos de objetivos para o programa de Mentoring ser realizado.

Exemplos de objetivos para programas de Mentoring incluem:

- Orientação e ajustes para a organização,

- Desenvolvimento de conhecimento e habilidades específicas,

- Desenvolvimento de core competências.

- Preparação de administração especifica ou habilidades de executivo,

- Aprendizado junto com a organização, 
- Atenção personalizada a todos.

- Melhoria na eficiência dos grupos,

- Desenvolvimento de times,

- Dicas e desenvolvimento de carreira,

- Aconselhamento e dicas relativas a problemas,

- Responsabilidade por grupos e indivíduos.

3. Procedimentos para funções de Mentoring são alinhados a cada conjunto de objetivos. podendo ser definidos tipos diferentes de relações de Mentoring para conjuntos diferentes de objetivos.

Exemplos de elementos a serem definidos para cada tipo de relação de Mentoring incluem:

- Os papéis e responsabilidades do mentor e dos individuos ou grupos,

- Como serão selecionados os mentores e serão treinados,

- Como individuos ou grupos receberão orientação em Mentoring,

- Como serão estabelecidas as relações de Mentoring,

- Como serão realizados os objetivos da relação,

- Como o programa será monitorado para ser eficiente,

* Como o programa será avaliado,

- A duração esperada da relação de Mentoring.

4. São definidos papéis para os mentores cumprirem.

Exemplos de papéis que os mentores podem cumprir incluem:

- Conselheiro pessoal ou de grupo.

- Conselheiro ou patrocinador de carreira,

- Desenvolvedor de conhecimentos e habilidades,

* Conselheiro de desempenho,

* Solucionador de problema.

- O perito.

5. Estruturas alternativas são consideradas para fornecer os tipos de beneficios alcançados pelo Mentoring.

Exemplos de aproximações alternativas para o Mentoring incluem:

- Círculos de Mentoring,

- Um grupo de processo de engenharia de software, 
- Outros grupos ou redes de suporte, tais como um grupo local de rede de melhoria de processo de software (SPIN).

Atividade 2 O programa de Mentoring é comunicado a todos os indivíduos ou grupos afetados.

Informações sobre o programa de Mentoring a serem comunicadas podem incluir:

1. Estrutura e metas do programa.

2. As posições, individuos, ou grupos cobertos no programa.

3. Procedimentos para voluntários atuarem como um mentor.

4. Procedimentos para incluir como um indivíduo ou grupo como receptor do Mentoring.

5. Orientação e treinamento exigidos.

Atividade 3 Indivíduos e/ou grupos são convidados a participar do programa de Mentoring.

1. A organização seleciona métodos para convidar a participação no programa de Mentoring baseado nos objetivos estabelecidos para o seu programa de Mentoring.

Exemplos de métodos que poderiam ser usados para convidar a participação no programa de Mentoring variam de solicitação ativa ao pessoal até anúncios passivos da disponibilidade do programa.

2. Um indivíduo é responsabilizado por responder perguntas sobre o programa de Mentoring.

Atividade 4: Mentores são selecionados e preparados para as suas tarefas.

1. Critérios são definidos para selecionar os mentores.

Exemplos de critérios para selecionar os mentores incluem:

- Experiência requerida ao mentor nas várias posições, indivíduos, ou grupos;

- Conhecimento requerido ao mentor nas várias posições, indivíduos, ou grupos;

- Habilidades de comunicação interpessoal;

- Habilidade para fornecer um modelo de papéis bem sucedido;

- Exigências de disponibilidade;

- Compromisso no desenvolvimento de conhecimentos e habilidades individuais;

- Habilidade para avaliar o desenvolvimento ou necessidades de carreira;

- Habilidade para fornecer direção em desempenho ou encarecimento de carreira;

- Habilidade para fornecer apoio pessoal; 
- Habilidade para trabalhar com grupos ou times;

- Compromisso em desenvolver e guiar outras pessoas.

2. São avaliados candidatos que solicitaram tarefas de Mentoring segundo um critério, e os que são qualificados são selecionados para atuar como mentores.

3. Os mentores selecionados são treinados nas responsabilidades e habilidades de Mentoring.

Atividade 5: Mentores são nomeados para indivíduos ou grupos.

Mentores são nomeados baseado em:

1. Requisitos organizacionais ou de distância gerencial entre o mentor e o indivíduo ou grupo que receberá programa.

2. Critérios de compatibilidade entre os mentores e os indivíduos ou grupos.

Exemplos de critérios de compatibilidade entre os mentores e os indivíduos ou grupos incluem:

- Tarefas, posição, ou experiências de carreira;

- Conhecimento e habilidades necessárias entre os indivíduos ou grupos que participarão do programa de Mentoring;

- Desenvolvimento pessoal necessário para o individuo participar do programa de Mentoring;

- Necessidades do grupo ou time de desenvolvimento;

- Conhecimentos anteriores comuns;

- Aspirações de carreira dos indivíduos ou grupos que participarão do programa de Mentoring;

- Habilidade para adaptar horários para reuniões;

- Personalidade ou interesses;

- Nível de envolvimento no Mentoring;

- Considerações geográficas.

3. Critério para manipular pedidos para tarefas específicas.

Atividade 6: Os mentores e os indivíduos ou grupos que participarão do programa estabelecem uma relação de Mentoring.

1. Tanto os mentores quanto os indivíduos ou grupos que participarão do programa recebem treinamento ou orientação apropriado antes de estabelecer a sua relação de Mentoring. 
2. Durante as reuniōes iniciais, os mentores e os indivíduos ou grupos estabelecem os acordos básicos nos quais a suas relação se desenvolverão.

Exemplos de assuntos que deveriam ser acordados incluem:

- O que ambos esperam alcançar com a relação de Mentoring.

- Se eles se encontrarão em eventos periódicos.

- Metas iniciais para realizar o Mentoring.

- Se eles construirão e seguirão um plano para os seus objetivos de desenvolvimento,

- Como eles avaliarão o próprio progresso,

- Como eles administrarão as reuniões,

- Como eles se comunicarão entre as reuniões.

3. Se o desenvolvimento de habilidades será parte da relação de Mentoring, eles avaliam e concordam em quais habilidades os indivíduo ou grupos precisam se desenvolver e como eles empreenderão esse desenvolvimento juntos.

4. O mentor fornece de maneira oportuna, feedback e liderança para os indivíduos ou grupos.

5. O mentor e o seu grupo continuamente discutem o desempenho no trabalho ou o comportamento individual ou do grupo e planejam as necessidades futuras de desenvolvimento.

Exemplos de assuntos que poderiam ser discutidos durante sessões de Mentoring incluem:

- Avaliação de desempenho e comportamento atual.

- Uso de tempo,

- Fixação de prioridades,

- Auto-administração,

- Estilo e habilidades interpessoal,

- Identificação de áreas que precisam de desenvolvimento,

- Analise de barreiras para o desempenho no trabalho ou para o crescimento de carreira,

- Identificação de mudanças necessárias em atitude ou estilos,

- Analise dos recursos e operações da organização,

- Analise das opções de carreira e habilidades necessárias.

Atividade $7 \mathrm{Um}$ direcionamento é disponibilizado aos mentores e aos indivíduos ou grupos de como melhorar a sua relação de Mentoring. 
Exemplos de direcionamento fornecidos para as relações de Mentoring incluem:

- Como iniciar a relação,

- Como ter reuniões freqüentemente,

- Tópicos potenciais a serem discutido.

- Como determinar as necessidades de Mentoring do indivíduo ou do grupo,

- Métodos para identificar os objetivos do Mentoring,

- Como identificar o progresso na relação de Mentoring,

- Como levar o trabalho ou os problemas de carreira,

- Como superar problemas na relação de Mentoring.

1. Um conselheiro deve estar disponível aos mentores ou aos indivíduos e grupos para discutir como tornar a relação de Mentoring mais efetiva.

2. Reuniões deveriam ocorrer de vez em quando para permitir aos mentores. indivíduos. ou grupos expressar suas preocupações ou melhorias que deveriam ser consideradas no programa de Mentoring.

Atividade 8 A relação de Mentoring é revisada periodicamente para assegurar que a relação está satisfazendo seus objetivos.

1. O mentor e os indivíduos ou grupos revisam periodicamente o progresso que eles estão fazendo em relação aỏ seu acordo de objetivos.

Atividade 9 Ações corretivas são tomadas para solucionar problemas nas relações de Mentoring.

Exemplos de ações corretivas incluem:

- Restabelecimento a base para a relação de Mentoring específica,

- Planejamento de reuniões ou ações mais efetivas,

- Aquisição de conselhos adicionais ou treinamento na administração de uma relação de Mentoring mais eficiente,

- Nomeação de um novo mentor ao indivíduo ou grupo.

Atividade 10 Os Mentores são reconhecidos pelo sucesso das atividades de Mentoring.

Exemplos de reconhecimento pelo sucesso para os mentores incluem:

- Prêmios,

- Reconhecimento público em reuniões ou jornais,

- Privilégios, 
- Considerações financeiras,

- Reconhecimento pelo sucesso no desempenho relacionado ao Mentoring ou nos objetivos de carreira.

\subsubsection{Medida e análise}

Medida 1: Medidas são realizadas e usadas para determinar o estado das atividades de . Mentoring.

Exemplos de medidas para determinar o estado das atividades de Mentoring incluem:

- O número de relações de Mentoring estabelecidas.

- A taxa na qual os candidatos aplicam para se tornar mentores,

- A eficiência com que relações de Mentoring novas são estabelecidas,

- A freqüência com que os mentores e individuos ou grupos interagem,

- A avaliação de atividades de Mentoring pelos individuos ou grupos,

- O número de problemas identificados e as melhorias feitas nas relações de Mentoring.

Medida 2: Medidas são realizadas e usadas para determinar o valor das atividades de Mentoring.

Exemplos de medidas para determinar o valor das atividades de Mentoring incluem:

- O crescimento de core competencies nos indivíduos ou grupos que estão no programa de Mentoring,

- A habilidade dos indivíduos ou grupos em usar os recursos da organização,

- O desempenho dos indivíduos ou grupos nas suas tarefas,

- O desenvolvimento de carreira dos indivíduos,

- O alinhamento da motivação dos indivíduos, grupos, ou times com os objetivos da organização.

\subsubsection{Verificação da Implementação}

Verificação 1: Um individuo é responsável por verificar quais atividades de Mentoring são administradas de acordo com o plano e as políticas documentadas da organização.

Estas revisões verificam se:

1. As atividades de Mentoring obedecem às políticas da organização e os valores declarados. 
2. Os itens de descumprimento são manipulados adequadamente.

3. São revisadas periodicamente todas as ações relacionadas a atividades de Mentoring para assegurar que elas estão conforme as políticas documentadas da organização.

Verificação 2: A efetividade da organização na implementação de um programa de Mentoring é periodicamente revisada pela administração executiva.

Estas revisões verificam:

1. A conveniência das atividades de Mentoring.

2. O progresso na execução das atividades de Mentoring.

3. Os resultados das revisões das atividades de Mentoring em relação aos valores da organização e as políticas apropriadas.

4. O estado de resolução dos assuntos de descumprimento.

\subsection{Processo de Implementação}

Baseado nessa complementação da revisão bibliográfica e visando o desenvolvimento de um processo de implantação das atividades de Comunicação e Mentoring desenvolveu-se para cada atividade um esquema que a resume e que serviu de base para elaborar o processo de implantação.

\subsubsection{Comunicação}

Como visto na complementação da revisão bibliográfica, a KPA Comunicação possui nove atividades que a implementam, essas atividades são apoiadas por três habilidades que devem ser pré-requisitos. Além disso, sua institucionalização é garantida por três compromissos permanentes e acompanhada por dois tipos de verificação e um tipo de medida.

Para deixar isso mais claro e facilitar a compreensão dessa KPA, foi criado um resumo esquemático da KPA Comunicação, ilustrado na figura 4.1. 


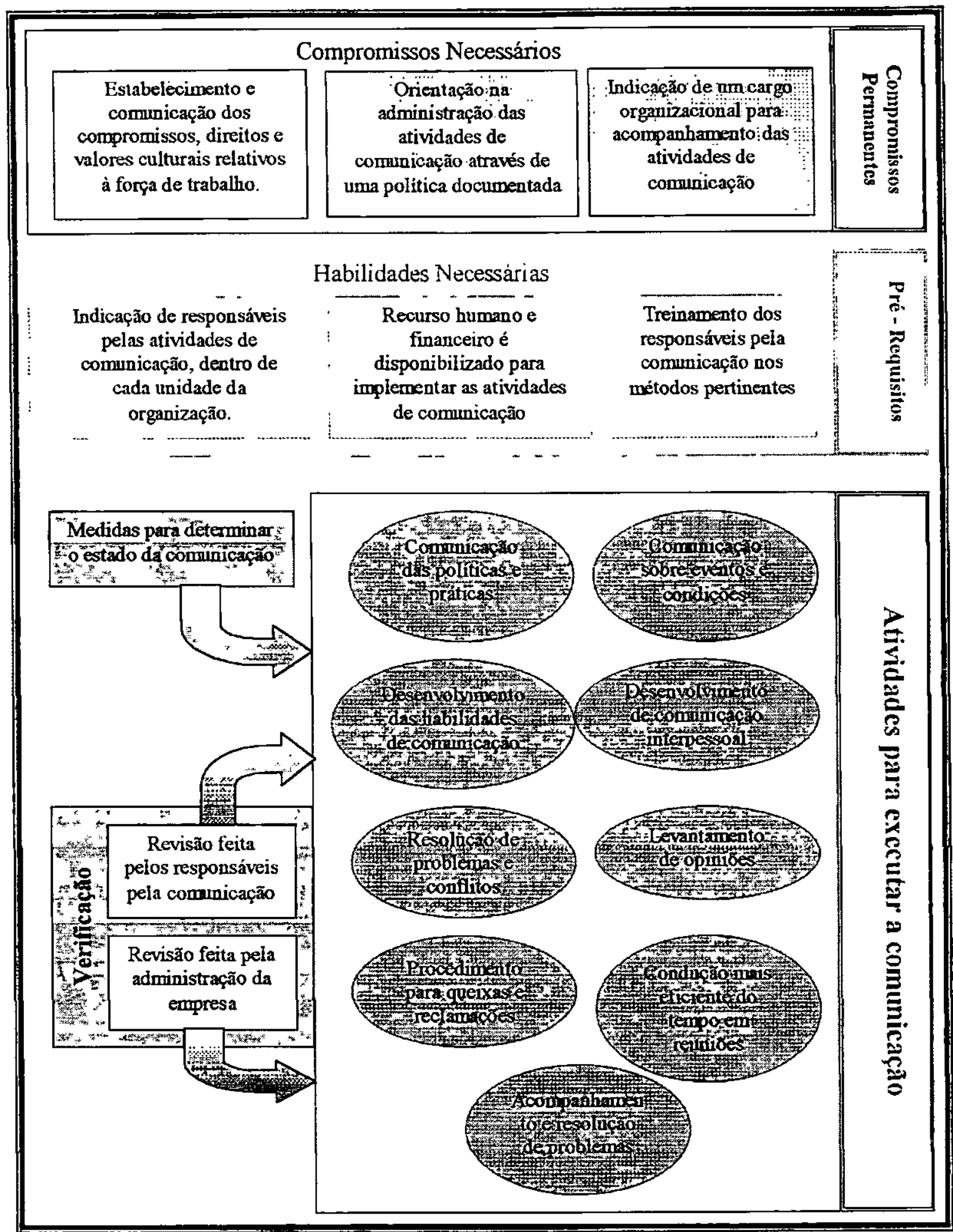

Figura 4-1: Resumo da KPA Comunicação

Baseado nesse esquema um exemplo de implantação da KPA comunicação em uma empresa que queira minimizar as barreiras durante a melhoria de processo poderia seguir os seguintes passos: 
- Pré-requisitos a serem preparados antes do inicio da melhoria de processo:

- São estabelecidos e comunicados os compromissos com o processo de mudança.

- São estabelecidas as mudanças culturais e melhorias esperadas com o processo de mudança,

- Todos os compromissos e mudanças de valores esperados são discutidos com toda a força de trabalho,

- Criam-se políticas e mecanismos para que os resultados de cada etapa da melhoria de processo sejam comunicados a todos,

- Todas essas políticas são documentadas e cobradas ao longo do processo.

- A área de recursos humanos fica incumbida de cobrar e guiar as pessoas na execução dessa política,

- Em cada grupo de trabalho uma pessoa é responsabilizada por comunicar periodicamente os resultados da melhoria de processo e das queixas e duvidas do seu grupo,

- A empresa fornece a área de recursos humanos os recursos financeiros e humanos necessários para executar as funções de comunicação,

- Os individuos responsáveis pela comunicação são treinados e orientados.

- Atividades de Comunicação a serem executadas durante a melhoria de processo:

- Todas as políticas e práticas que a organização terá em relação a sua força de trabalho durante a melhoria de processo devem ser claramente comunicadas,

- Todo e qualquer evento organizacional é comunicado periodicamente através do correio eletrônico,

- Todos na empresa são treinados nos termos e jargões do modelo de melhoria de processo escolhido,

- Todos na empresa participam de dinâmicas de grupo e são treinados para interagirem com eficiência durante as fases da melhoria de processo,

- Opiniões divergentes ou conflitos de qualquer natureza que aconteçam na implantação da melhoria do processo devem ser resolvidos rápida e habilmente, 
- Periodicamente todos devem enviar por̀ correio eletrônico sua opinião sobre o andamento da melhoria do processo,

- A qualquer momento os indivíduos ou grupos podem apresentar queixas ou reclamações, através de um procedimento pré-determinado,

- A resolução de toda e qualquer reclamação é acompanhada de perto pela administração, evitando que problemas e descontentamentos com a melhoria se acumulem,

- Reuniões são marcadas com antecedência, dizendo o assunto a ser tratado a responsabilidade de cada um, a localização e o horário da reunião,

- Medidas a análises a serem feitas periodicamente:

- Estatística das opiniões enviadas,

- Número de reclamações,

- Número de conflitos resolvidos,

- Tempo gasto na resolução de conflitos.

- A verificação da Comunicação na empresa deve ser feita periodicamente:

- Por um responsável da área de recursos humanos que verifica se as atividades de comunicação estão adequadas ao que foi estipulado e se os itens que não estão de acordo estão sendo resolvidos adequadamente,

- Pelo executivo responsável pela melhoria de processo que verifica itens como número de queixas levantadas e resolvidas, estado das resoluções de problemas e se a comunicação está como esperado.

O esquema da figura 4.2 apresenta os passos da implantação, fornecendo uma idéia geral de como este trabalho visualiza o funcionamento da KPA Comunicação durante a melhoria de processo de software. 


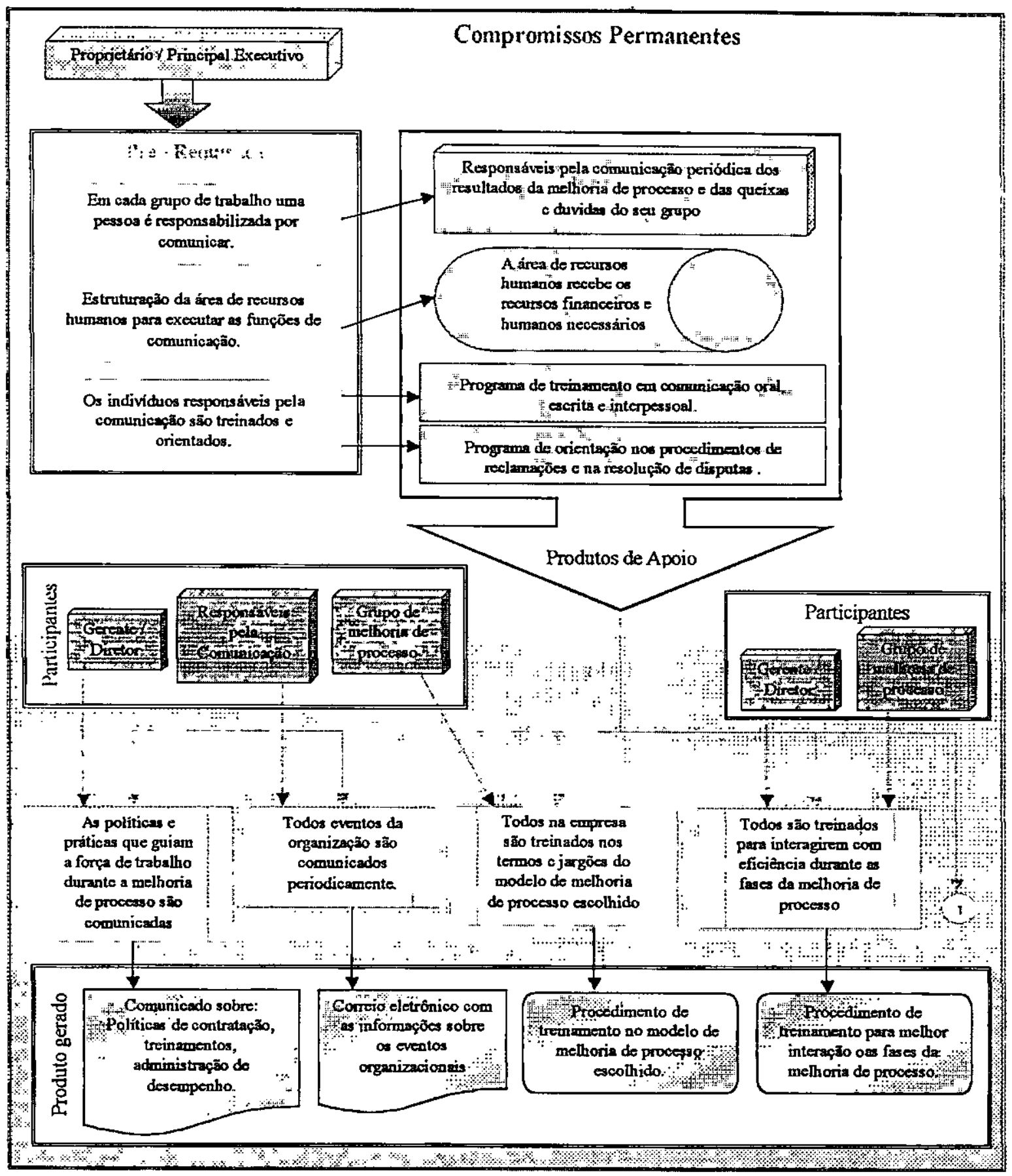

Figura 4-2: Processo de implantação da Comunicação 


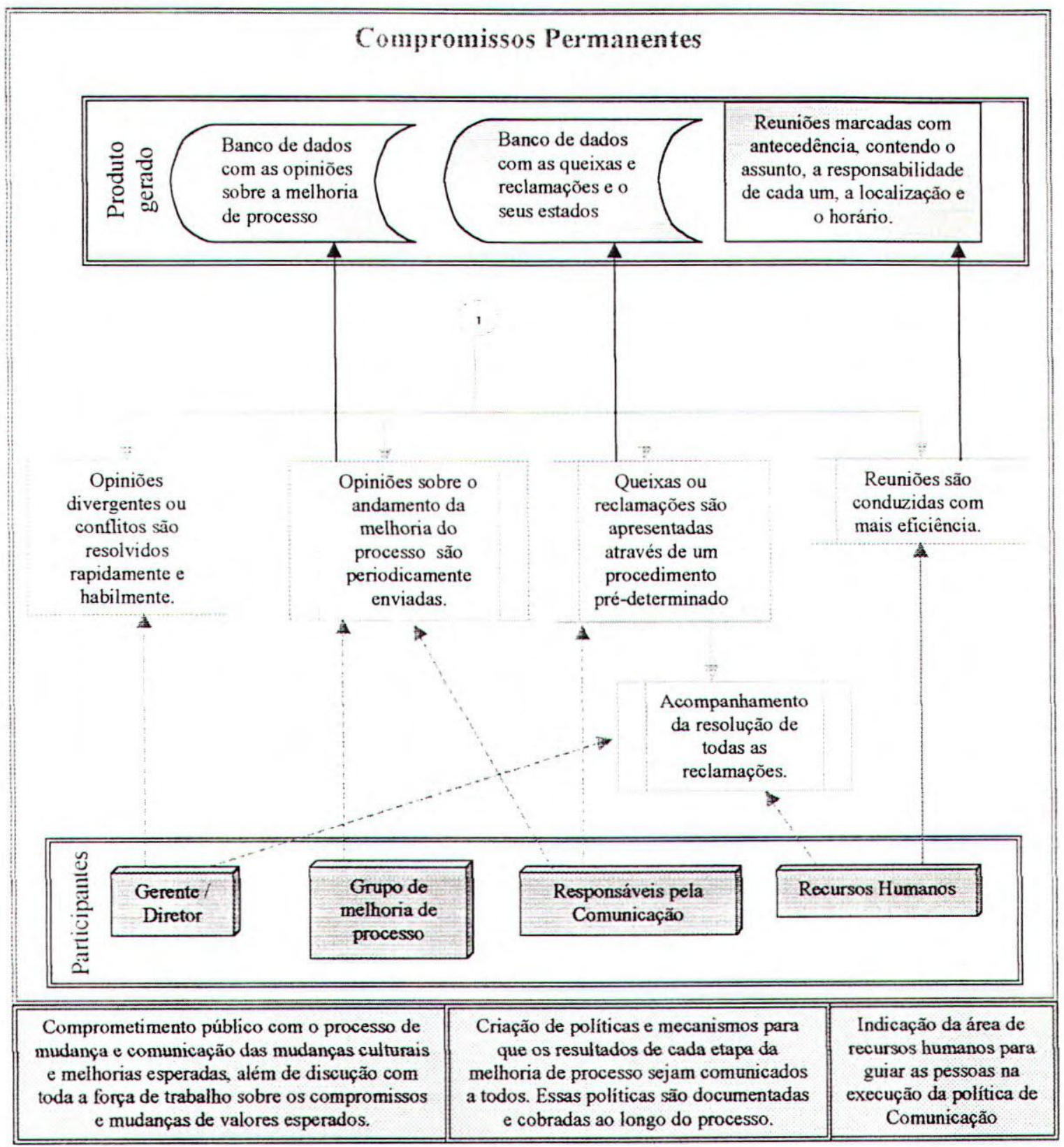

Figura 4.2: Processo de implantação da Comunicação - Continuação

\subsubsection{Mentoring}

Como visto na complementação da revisão bibliográfica, a KPA Mentoring possui dez atividades que a implementam, essas atividades são apoiadas por quatro habilidades que devem ser pré-requisitos. Além disso, sua institucionalização é garantida por dois compromissos permanentes e acompanhada por dois tipos de verificação e dois tipos de medidas.

Para deixar isso mais claro e facilitar a compreensão dessa KPA, foi criado um resumo esquemático da KPA Mentoring, ilustrado na figura 4.3. 


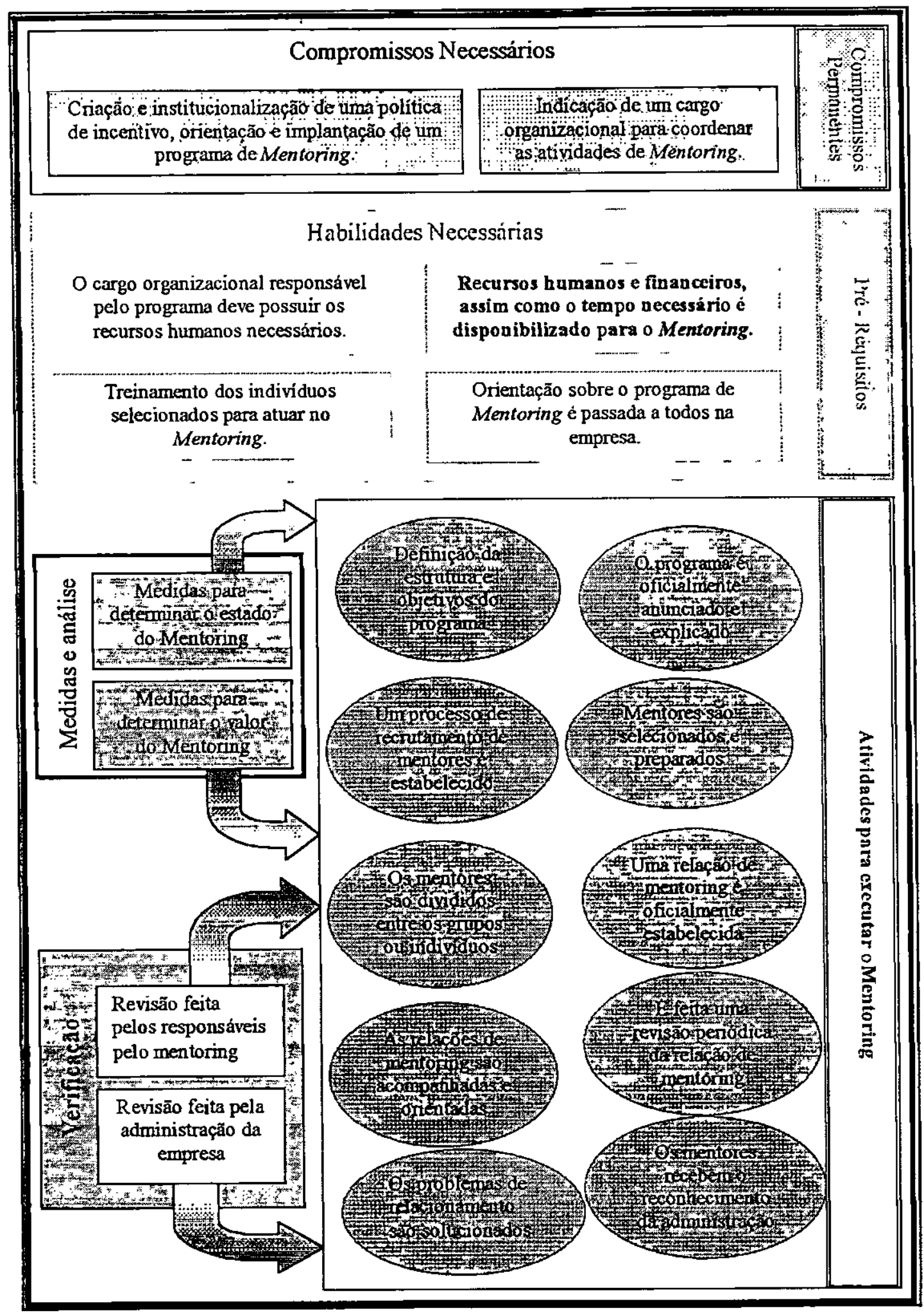

Figura 4-1: Resumo da KPA Mentoring

Baseado nesse esquema um exemplo de implantação da KPA Mentoring em uma pequena empresa, que queira minimizar as barreiras durante a melhoria de processo, poderia considerar os seguintes passos: 
- Pré-requisitos a serem preparados antes do inicio da melhoria de processo:

- Uma estratégia de atuação para o programa de Mentoring é estabelecida,

- A estratégia alinha as dificuldades esperadas no processo com os objetivos da organização,

- Cria-se um procedimento de controle e atuação do Mentoring,

- Uma área ou gerência é indicada para cuidar do programa de Mentoring,

- No caso da área indicada não possuir os recursos necessários, recursos humanos (individuos experientes) e financeiros (treinamento) são disponibilizados,

- Os mentores selecionados são treinados e orientados nas habilidades especificas da nova função,

- Todos na empresa devem ser conscientizados dos objetivos e benefícios do Mentoring.

- Atividades para implantar o Mentoring durante a melhoria de processo:

- É definido junto ao grupo de melhoria de processo de software, o perfil necessário ao mentor, as core competence que serão desenvolvidas por eles no restante da força de trabalho, as habilidades e conhecimentos a serem desenvolvidos e como os mentores se comprometerão com os indivíduos e grupos,

- As regras e estruturas do programa, assim como as exigências para atuação como mentor são divulgadas oficialmente a todos através de mecanismos criados pela KPA comunicação,

- Anúncios em quadros de aviso e por correio eletrônico são feitos para recrutar indivíduos a atuar como mentores,

- De acordo com a experiência e influência do indivíduo junto à força de trabalho e baseado nos critérios pré estabelecido junto ao grupo de melhoria de processo os mentores são selecionados,

- Cada mentor é responsabilizado por um ou mais grupos ou indivíduos de acordo com seus conhecimentos técnicos e afinidade com o grupo, 
- Através de reuniões e palestras é criada a relação de Mentoring entre os grupos e os mentores. Para isso os objetivos, expectativas e procedimentos de atuação do mentor são estabelecidas em conjunto e um comprometimento é criado,

- A área responsável pelo Mentoring deve mediar essas reuniões e evoluir o relacionamento através de conselhos e orientação,

- Periodicamente revisa-se a relação de Mentoring para garantir que ela não esteja criando problemas ao invés minimizando as barreiras à melhoria de processo,

- Problemas de relacionamento durante o Mentoring devem ser rapidamente solucionados, através de reuniões e conselhos ou remanejando-se os mentores nos grupos,

- Os mentores devem ser reconhecidos pelo sucesso no Mentoring como em qualquer outro projeto.

- Medidas a análises a serem feitas periodicamente:

- Número de problemas identificados e as melhorias feitas nas relações de Mentoring,

- A freqüência com que os mentores interagem com seus grupos ou indivíduos,

- A avaliação das atividades de Mentoring pelos indivíduos ou grupos.

- Crescimento de core competencies nos indivíduos ou grupos que estão no programa de Mentoring,

- O desempenho dos indivíduos ou grupos nas suas tarefas,

- O comprometimento dos indivíduos ou grupos com o programa de melhoria de processo.

- A verificação do programa de Mentoring na empresa deve ser feita periodicamente:

- Pela área responsável pelo programa que verifica se as atividades de Mentoring estão adequadas ao que foi estipulado e se os itens que não estão de acordo estão sendo resolvidos adequadamente,

- Pelo executivo responsável pela melhoria de processo que verifica itens como conveniência do programa de Mentoring, o progresso na execução das atividades de Mentoring, o resultado das revisões das atividades de Mentoring. 
O esquema da figura 4.2 apresenta os passos da implantação, fornecendo uma idéia geral de como este trabalho visualiza o funcionamento da KPA Mentoring durante a melhoria de processo de software.

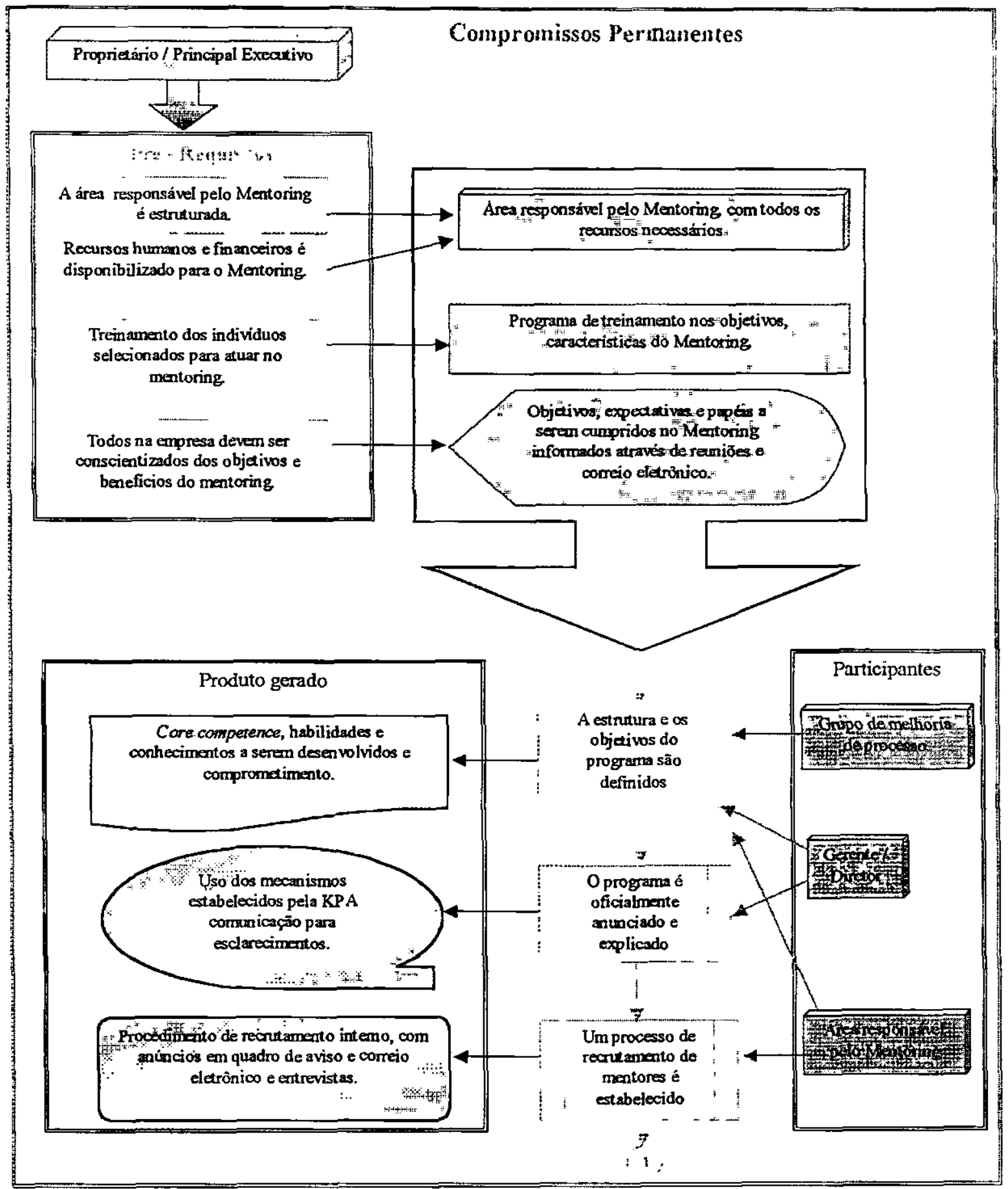

Figura 4-2: Processo de implantação do Mentoring 


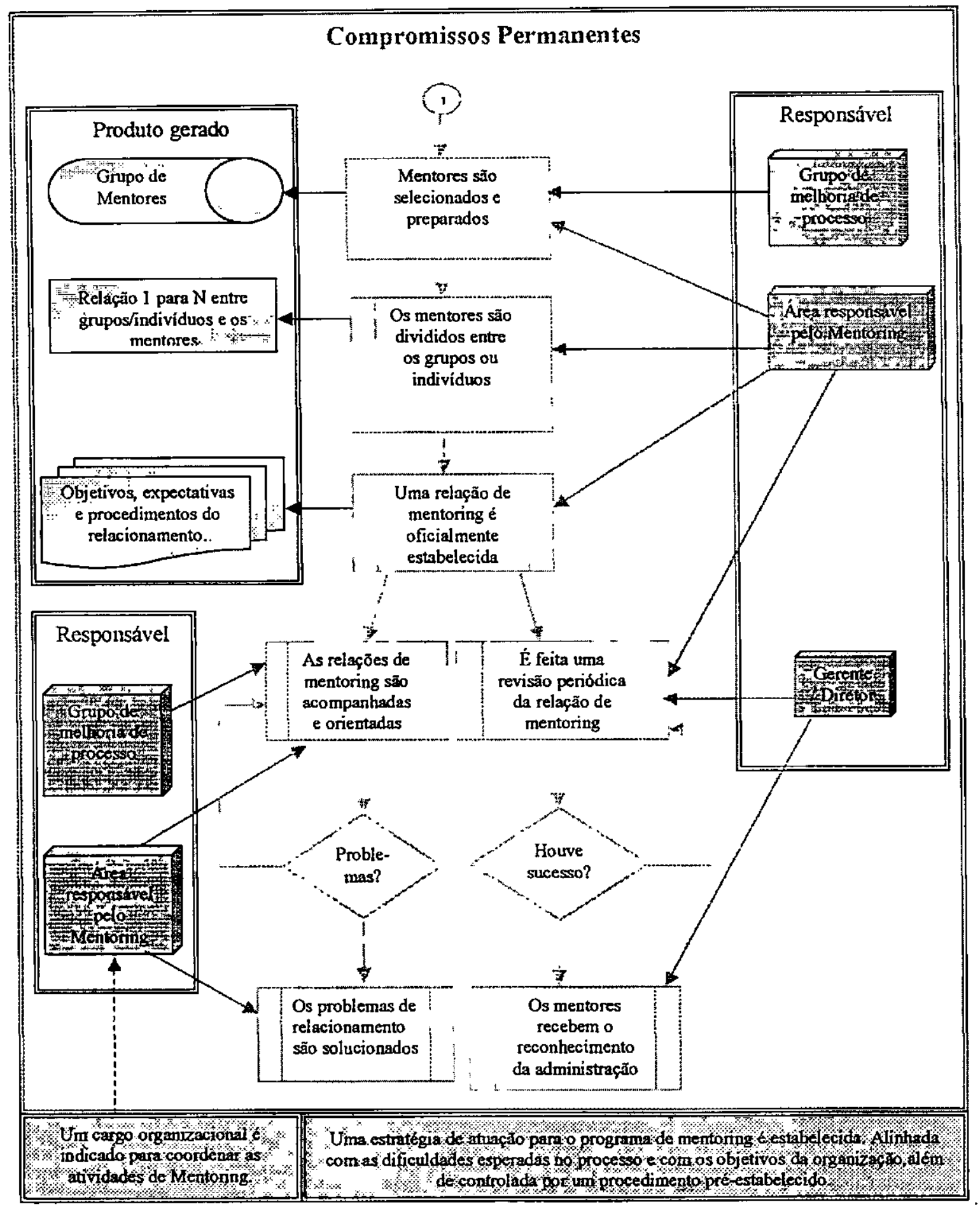

Figura 4.4: Processo de implantação do Mentoring - Continuação 


\subsection{Considerações Finais}

$\mathrm{O}$ trabalho realizado até aqui foi o de interpretação do P-CMM através de um contexto específico. Com o apoio das teorias administrativas de gerenciamento de pessoas e administração de mudanças. visualizou-se o P-CMM como ferramenta para agilizar a melhoria de processo e a busca da qualidade do software. Além disso, identificou-se atividades essenciais para viabilizar a melhoria de processo de software e estruturou-se um procedimento de implantação dessas atividades.

No próximo capítulo são analisados esses resultados para extrair-se as conclusões e implicações deste trabalho. Além disso, com base nas próprias conclusões, identifica-se as possibilidades de novos trabalhos como continuidade deste. 
Os modelos de melhoria de processo atuais como Capability Maturity Model for Software, possuem um sólido framework que utiliza as boas práticas da engenharia de software para melhorar continuamente a qualidade do processo de software e conseqüentemente a qualidade do software. Mesmo com toda essa tecnologia e evolução muitas implantações desses modelos terminam em fracasso.

Na tentativa de explicar muitos dos insucessos de projetos de melhoria de processo de software, mostrou-se que a mudança no processo de desenvolvimento passa necessariamente pelos seus recursos humanos e a resistência das pessoas é uma das maiores fontes de insucesso dos processos de mudança. Mostrou-se também que realmente a qualidade de software é fruto da trilogia, tecnologia, processo e pessoas, que participam do processo de desenvolvimento de software.

A resistência das pessoas, a falta de comprometimento e a desinformação são alguns dos problemas normalmente encontrados durante a implantação da melhoria de processo de software. Por traz desses problemas, está a falta de visão que os responsáveis pela melhoria do processo de software tem da interligação dos recursos que formam os sistemas organizacionais e que conseqüentemente afetam drasticamente o sucesso desses programas.

Identificada as barreiras e dificuldades impostas pelas pessoas em um processo de mudança, a ambientação para a realidade da melhoria de processo de software foi feita com a ajuda do P-CMM (People Capability Maturity Model), um modelo de maturidade para o desenvolvimento do talento humano, desenvolvido pela SEI (Software Engineering Institute, pertencente à universidade Carnegie Mellon), que tem como objetivo estratégico a melhoria das capacidades das organizações de software, através do aumento da capacidade da sua força de trabalho.

O P-CMM busca melhorar os desenvolvedores de software e a maneira como a organização os administra. Neste trabalho mostrou-se que essas idéias valem não só no contexto geral, mas podem ser muito úteis na melhoria de processo, pois torna os desenvolvedores parte do processo de melhoria. 
Pensando-se no triângulo que influência a qualidade do software formado por tecnologia. processo e pessoas, o P-CMM é hoje a ferramenta da qualidade de software que atua no vértice das pessoas. A nova visão dada ao P-CMM neste trabalho tenta aproximar um pouco esse vértice, ainda pouco comentado, aos vértices tecnologia e processo.

Apesar de ficar claro como cada KPA pode auxiliar no programa de melhoria de processo. nem todas as empresas podem implantar todo o P-CMM junto com a melhoria de processo. Na busca de KPAs do P-CMM que possam ajudar na mudança cultural e na quebra de barreiras ao projeto de melhoria de processo, este trabalho deparou com o fato de não encontrar qualquer KPA que ao menos indiretamente não colaborasse com esse objetivo.

Diante dessa conclusão e baseado nas teorias administrativas sobre agentes facilitadores de mudança e em características da maioria das empresas de software brasileiras, selecionou-se duas KPAs imprescindiveis para a viabilização de um programa de melhoria de processo: Comunicação e Mentoring.

Para essas duas KPAs foi elaborado um processo de implantação pensando-se na melhoria de processo. Esse procedimento não é um modelo testado e comprovado, nem o único caminho existente para agilizar a melhoria de processo. O que foi desenvolvido aqui, trata-se de uma interpretação do P-CMM e uma aplicação dessa interpretação.

A implantação dessas KPAs conforme o processo desenvolvido, não especifica a ordem de implantação nem o momento. No entanto uma análise dos dois procedimentos deixa claro que o ideal é iniciar a implantação dessas KPAs antes do programa de melhoria de processo e com primeiro foco na Comunicaçāo.

O que se pode concluir com clareza é que durante a melhoria de processo de software é imprescindível a necessidade de levar em conta as pessoas envolvidas, e que um bom processo de comunicação e um programa de acompanhamento eficiente e bem estruturado pode ajudar enormemente. O problema é que com a mesma certeza que se chega a essa conclusão, percebe-se que mesmo o exemplo de implantação criado neste trabalho não é fácil de ser executado. Isso por que trata-se de um programa complexo que exige tempo e recursos humanos, fatores escassos para a maioria das empresas brasileiras.

De qualquer maneira vale ressaltar que apesar de nạ̃o ser fácil implantar um processo eficiente de Comunicação e um programa de Mentoring, não implanta-los com certeza traz maiores dificuldades e maiores gastos. Além disso, em muitos casos o esforço em tornar a 
Comunicação e o Mentoring realidades pode ser a diferença entre o fracasso e o sucesso da melhoria de processo.

\subsection{Trabalhos Futuros}

Este trabalho trouxe novos conceitos para a área de engenharia de software, mostrando um novo caminho de pesquisas. Esses novos caminhos começam na continuação direta deste trabalho, ou seja, na validação dos processos de implantação das KPAs Comunicação e Mentoring para identificar melhorias e correções.

Ainda como continuação deste trabalho poderiam ser identificados procedimentos de implantação para as outras KPAs, mostrando-se como as empresas podem dar continuidade ao programa de melhoria e comprometimento dos recursos humanos.

Outra frente de pesquisa baseada neste trabalho que ainda não foi abordada e tem muito a oferecer seria o de buscar a integração dos três recursos que afetam a qualidade do software tecnologia, processo e pessoas. Essa linha de pesquisa poderia ter como meta a criação de um modelo de qualidade híbrido que juntasse o SW-CMM e o P-CMM ou ao menos um processo de implantação conjunta desses modelos. Nesse contexto, poder-se-ia estudar vínculos entre as KPAs dos dois modelos, identificando-se quais KPAs de um modelo podem influenciar nas KPAs do outro.

De qualquer maneira, mais importante que tornar este trabalho um modelo ou de aplicar sua interpretação em diversos projetos de melhoria de processo é entender a motivação da pesquisa, ou seja, entender que o desenvolvimento de software é formado pela trilogia tecnologia, processo e pessoas; e entender também que se pode administrar melhor as pessoas envolvidas no desenvolvimento de software e na melhoria de processo, mas não sem trabalho e planejamento.

Dessa maneira acredita-se que qualquer trabalho que possa levar essa visão para quem trabalha com qualidade de software contribuiria muito com a evolução do desenvolvimento de software. 


\section{BIBLIOGRAFIA}

\subsection{Referências bibliográficas}

(Appleton, 1997) APPLETON, BRAD. Patterns for Conducting Process Improvement. http://wwww.enteract.com/ hradapg/, PloP'97 conference, 1997

(Bio, 1985) BlO, S.R. Sistemas de Informação: Um Enfoque Gerencial. São Paulo. Atlas 1985.

(Bitencourt, 1996) BITENCOURT, CLAUDIA: RUAS, ROBERTO. Mudança organizacional: Um estudo dos agentes facilitadores, XIX Simpósio de gestão da inovação tecnológica.

(Castro, 1994) CASTRO, DURVAL MUNIZ DE. A motivação através do ciclo de qualidade. Revista de Administração, São Paulo, v.29, n.2, p.32-37, abril/junho, 1994.

(Chiavenato, CHIAVENATO, IDALBERTO. Introdução à teoria geral da administração. $4^{a}$ 1993) ed, Makron Books, 1993.

(Curtis et all, CURTIS, BILL; HEFLEY, WILLIAM E.; MILLER, SALLY. People Capability 1995) Maturity Model ${ }^{\text {SNI }}$. Setembro, 1995. Maturity Model, CMU/SEI-95-MM-02.

(Fleury, 1989) FLEURY, MARIA T. L. Cultura organizacional - Os modismos, as pesquisas, as intervenções: uma discussāo metodológica, Revista de Administração. São Paulo, v.24, n.2, p.3-9, janeiro/março, 1989.

(Fleury, 1991) FLEURY, MARIA T. L. Cultura organizacional e estratégias de mudanças: recolocando estas questões no cenário brasileiro atual, Revista de Administração, São Paulo, v.26, n.2, p.3-11, abril/junho, 1991.

(Fleury, 1997) FLEURY, A.; FLEURY, M.T.L. Aprendizagem e inovação organizacional: As experiências de Japão, Coréia e Brasil. 237p., 2ed, São Paulo, Atlas, 1997.

(Hampton, 1992) HAMPTON, DAVID R. Administração Contemporânea: teoria, prática e casos, $3^{\text {a }}$ ed., McGraw-Hill, 1983, 1992.

(Marcondes, MARCONDES, ODINO. Mudança da cultura X Cultura da mudança. 1996) http://www.elementohumanc.com.br/mudanca.html, 1985.

(Melo, 1991) MELO, MARLENE C. O. L. Produto e produtores da cultura organizacional: algumas questões sobre o comportamento dos empregados, Revista de Administração, São Paulo. v.26, n.2, p.60-67, abril/junho, 1991. 
(Qualidade, 1997) Qualidade no Setor de Software Brasileiro 1997. Brasília, Secretária de Política de Informática e Automação, 1998, N.2.

(Rodrigues, 1995) RODRIGUEZ, M., FERRANTE, A. J. A Tecnologia De Informação E Mudança Organizacional. Rio De Janeiro: Infobook, 1995.

(Schein, 1986) SCHEIN, EDGAR H. Organizational culture and leadership. San Francisco. Jossey Bass, 1986.

(Schein, 1992) SCHEIN, EDGAR H. Organizational culture and leadership. $2 "$ ed. San Francisco, Jossey Bass, 1992. [Edição Revisada]

(Siddall, 1997) SIDDALL, DON. Understanding and Managing Resistence. Software Process Newsletter, No 9, Spring, 1997.

(Vasconcellos et VASCONCELLOS, E.; HEMSLEY, J.R. Estrutura das organizações: Estruturas all) Tradicionais, Estruturas para Inovação e Estrutura Matricial, Biblioteca Pioneira de Administração de Negócios, $2^{\circ}$ edição, São Paulo

\subsection{Referências Complementares}

(Fleury, 1995) FLEURY, MARIA T. L. Aprendendo a mudar - aprendendo a aprender, Revista de Administração, São Paulo, v.30, n.3, p.5-11, julho/setembro, 1995.

(Maximiano et all, MAXIMIANO, A. C. A.; SBRAGIA, R.; KRONER, W. O gerente do projeto 1996) "Peso Pesado": Um estudo de caso, XIX Simpósio de gestão da inovação tecnológica.

(Maximiano, MAXIMIANO, A. C. A. O gerente de projetos: um "ator" com vários 1988) personagens, Revista de Administração, São Paulo, v.23, n.2, p.93-98, abril/junho, 1988.

(Maximiano, MAXIMIANO, ANTONIO CESAR AMARU. Novos modelos de organização de 1996) projetos, XIX Simpósio de gestão da inovaçāo tecnológica.

(Maximiano, MAXIMIANO, ANTONIO CESAR AMARU. Administraçāo de projetos: como 1997) transformar idéias em resultados. 196p., São Paulo, Atias, 1997.

(Shragia, 1986) SBRAGIA, R.; MAXIMIANO, A. C. A.; KRUGLIANSKAS, I. O gerente de projetos: seu papel e habilidades, Revista de Administração, São Paulo, v.21, n.3, p.24-319, julho/setembro, 1986.

(Schein, 1993) SCHEIN, EDGAR $H$. How can organizations learn faster? The challenge of entering green room. P85-92, SMR Forum, Winter, 1993. 